\title{
Eocene mammals from volcaniclastic deposits of the Somun Cura Plateau: biostratigraphic implications for north Patagonia Paleogene
}

\author{
*Alejandro Kramarz ${ }^{1}$, Eduardo Bellosi' ${ }^{1}$, Mariano Bond ${ }^{2}$, Analía M. Forasiepi \\ Juan Carlos Fernicola ${ }^{1}$, Guillermo Aguirrezabala ${ }^{1}$, Daniella Teixeira de Rezende ${ }^{1}$
}

${ }^{1}$ Consejo Nacional de Investigaciones Cientificas y Técnicas (CONICET), Museo Argentino de Ciencias Naturales. Av. Angel Gallardo 470, 1405, C.A.B.A., Argentina.

agkramarz@macn.gov.ar; beledu00@gmail.com; jctano@yahoo.com; guillecomallo@yahoo.com.ar;daniellatr.bio@gmail.com

2 Consejo Nacional de Investigaciones Cientificas y Técnicas (CONICET), Depto. Cientifico Paleontología de Vertebrados, Museo de La Plata, Paseo del Bosque s/n, 1900 La Plata, Buenos Aires, Argentina.

constantino1453@yahoo.com.ar

${ }^{3}$ Consejo Nacional de Investigaciones Cientificas y Técnicas (CONICET), IANIGLA. Av. Ruiz Leal s/n, Parque Gral. San Martín, 5500 Mendoza, Argentina.

borhyaena@hotmail.com

* Corresponding author:agkramarz@macn.gov.ar

\begin{abstract}
The Paleogene terrestrial faunal succession and its associated bearing volcaniclastic deposits has been exhaustively studied in central Patagonia, but there is still no acceptable litho-bio-chronostratigraphic ordering for the extra-Andean North Patagonia. The only references on Paleogene mammals bearing deposits north to Chubut River are imprecise and contradictory. West to Ingeniero Jacobacci (Río Negro Province, Argentina), the paleontologist and archaeologist Rodolfo Casamiquela reported a fossiliferous succession with Casamayoran or Mustersan (Eocene) and Deseadan (Oligocene) mammals from rocks currently mapped as the Las Chacras Formation. This unit includes acid to intermediate tuffs, ignimbrites, paleosols, conglomerates, and basalts originated in a perivolcanic fluvial system, under a seasonal subhumid-humid climate according to predominant pedogenic features. As a result of our fieldworks and fossil collection in the area of Ingeniero Jacobacci, and the revision of the materials collected by Casamiquela in the forties and fifties (with well-known stratigraphic origin), we identified a single mammal association from the lower section of the Las Chacras Formation (here named the Lower Las Chacras fauna) composed by: Plesiofelis schlosseri Roth, 1903 (Sparassodonta), Trigonostylops Ameghino, 1897, Astraponotus Ameghino, 1901 (Astrapotheria), Propyrotherium Ameghino, 1901 (Pyrotheria), Pseudhyrax eutrachytheroides Ameghino, 1901, Eohegetotherium priscum Ameghino, 1901, Puelia sigma (Ameghino, 1901), Periphragnis Roth, 1899 (Notoungulata), Isutaetus depictus Ameghino, 1902 (Cingulata), and a new member of Adianthidae (Litopterna) and probably of Pichipilidae (Paucituberculata). This assemblage is closer to that derived from the Rosado Member of the Sarmiento Formation at Gran Barranca, central Patagonia (type locality of the Mustersan Land Mammal Age) dated in $c a .38 \mathrm{Ma}$ (late middle Eocene). A pyroclastic flow associated to the bearing deposits of Ingeniero Jacobacci was dated (K-Ar) in $39.2 \pm 2 \mathrm{Ma}$, value compatible with the Mustersan age here inferred for the Lower Las Chacras fauna. The alleged occurrence of Deseadan mammals in these levels was based on remains of an isotemnid notoungulate incorrectly identified as a leontinid. The presence of the Tinguirirican (early Oligocene) notoungulate Eohegetotherium priscum, with more apomorphic dental traits than in its Eocene allies, and of an astrapotheriid more derived than Astraponotus suggests that some advanced faunal elements would have been established in North Patagonia earlier than in central Patagonia.
\end{abstract}


RESUMEN. Mamíferos eocenos en depósitos volcanoclásticos de la meseta de Somun Cura: implicaciones bioestratigráficas para el Paleógeno del norte de la Patagonia. La sucesión faunística terrestre del Paleógeno y sus depósitos volcaniclásticos portadores asociados han sido exhaustivamente estudiados en la Patagonia central, pero aún no hay un ordenamiento litobiochronoestratigráfico aceptable para la región Norpatagónica extrandina. Las únicas referencias sobre depósitos portadores de mamíferos paleógenos al norte del río Chubut son imprecisas y contradictorias. Al oeste de Ingeniero Jacobacci (Provincia de Río Negro, Argentina), el paleontólogo y arqueólogo Rodolfo Casamiquela reportó una sucesión fosilífera con mamíferos casamayorenses o mustersenses (Eoceno) y deseadenses (Oligoceno) de rocas actualmente mapeadas como Formación Las Chacras. Esta unidad incluye tobas ácidas a intermedias, ignimbritas, paleosuelos, conglomerados y basaltos originados en un sistema fluvial perivolcánico, bajo un clima estacional subhúmedo de acuerdo con los caracteres pedogénicos predominantes. Como resultado de nuestros trabajos de campo y recolección de fósiles en el área de Ingeniero Jacobacci y de la revisión de los materiales colectados por Casamiquela en los años cuarenta y cincuenta (con procedencia estratigráfica bien conocida), identificamos una única asociación de mamíferos proveniente de la sección inferior de la Formación Las Chacras (aquí denominada "Lower Las Chacras fauna") compuesta por Plesiofelis schlosseri Roth, 1903 (Sparassodonta); Trigonostylops Ameghino, 1897; Astraponotus Ameghino, 1901 (Astrapotheria); Propyrotherium Ameghino, 1901 (Pyrotheria); Pseudhyrax eutrachytheroides Ameghino, 1901; Eohegetotherium priscum Ameghino, 1901; Puelia sigma (Ameghino, 1901); Periphragnis Roth, 1899 (Notoungulata); Isutaetus depictus Ameghino, 1902 (Cingulata); y un nuevo miembro de Adianthidae (Litopterna) y probablemente de Pichipilidae (Paucituberculata). Esta asociación es más parecida a la proveniente del Miembro Rosado de la Formación Sarmiento en Gran Barranca, Patagonia central (localidad tipo de la Edad Mamífero Mustersense) datada en ca. $38 \mathrm{Ma}$ (Eoceno medio tardío). Un flujo piroclástico asociado a los depósitos portadores de Ingeniero Jacobacci fue datado (K-Ar) en 39,2 \pm 2 Ma, valor compatible con la edad Mustersense inferida aquí para la "Lower Las Chacras fauna". La supuesta presencia de mamíferos deseadenses en estos niveles estaba basada sobre restos de un notoungulado isotémnido incorrectamente identificado como un leontínido. La presencia del notoungulado tinguiririquense (Oligoceno temprano) Eohegetotherium priscum, con caracteres dentarios más apomórficos que sus aliados eocénicos, y de un astrapotérido más derivado que Astraponotus, sugiere que algunos elementos faunísticos más avanzados se habrían establecido en la Norpatagonia más temprano que en la Patagonia central.

Palabras clave: Paleógeno, Edad Mustersense, Ingeniero Jacobacci, Formación Las Chacras, Mamíferos fósiles, Bioestratigrafia.

\section{Introduction}

The Andean foreland of central Patagonia was draped by a huge volume of volcanic ashes and coarser volcaniclastic sediments during much (30 Ma) of the middle Cenozoic (Feruglio, 1949; Mazzoni, 1985; Bellosi, 2010a). This process involved both large depocenters (e.g., San Jorge, Cañadón Asfalto, Valdés basins) and smaller, low-subsiding areas related to valleys infills. These volcaniclastic deposits preserved a vast number of fossil remains that document the Paleogene-early Neogene evolution of mammals and other vertebrates in continental landscapes of southern South America. Age and divisions of the volcaniclastic successions were defined according to fossil mammals grouped into several assemblages (Ameghino, 1900-1902, 1906), that later became the standards for the South America land mammal ages (SALMAs) (e.g. Simpson, 1940; Pascual et al., 1965). The stratigraphic framework, chronology, and allocation of SALMAs for this Paleogeneearly Neogene succession (mostly the Sarmiento Formation and equivalents) was outlined in central Patagonia, particularly at the Gran Barranca South of Colhué-Huapi Lake (Bellosi, 2010b; Ré et al., 2010; Dunn et al., 2013; Bellosi and Krause, 2014) (Fig. 1). However, stratigraphy, chronology, and fossil mammal content of coeval deposits in North Patagonia are not well delineated yet (Franchi et al., 1984; Ardolino et al., 1999). There are very few documented occurrences of Paleogene mammals in rocks exposed north of the Chubut River. They include the still little known early Oligocene association from the Bajada de los Ingleses Formation at Río Negro Province (Bond et al., 1997), and undetermined deposits in Neuquén Province presumably bearing Eocene and Oligocene mammals (Ameghino, 1889, 1906; Kraglievich, 1957; Kramarz et al., 2011). Somewhat better documented are the Paleogene volcaniclastic deposits interbedded with lava flows at the west slope of the Somun Cura Plateau in Río Negro Province, near Ingeniero Jacobacci (Ardolino et al., 1999) (Fig. 1).

During the late forties and early fifties, the Argentine archaeologist and paleontologist Rodolfo Casamiquela collected several fossil remains in the vicinities of Ingeniero Jacobacci, at the area of Puesto Marileo, a site also known locally as 
A

\section{B}

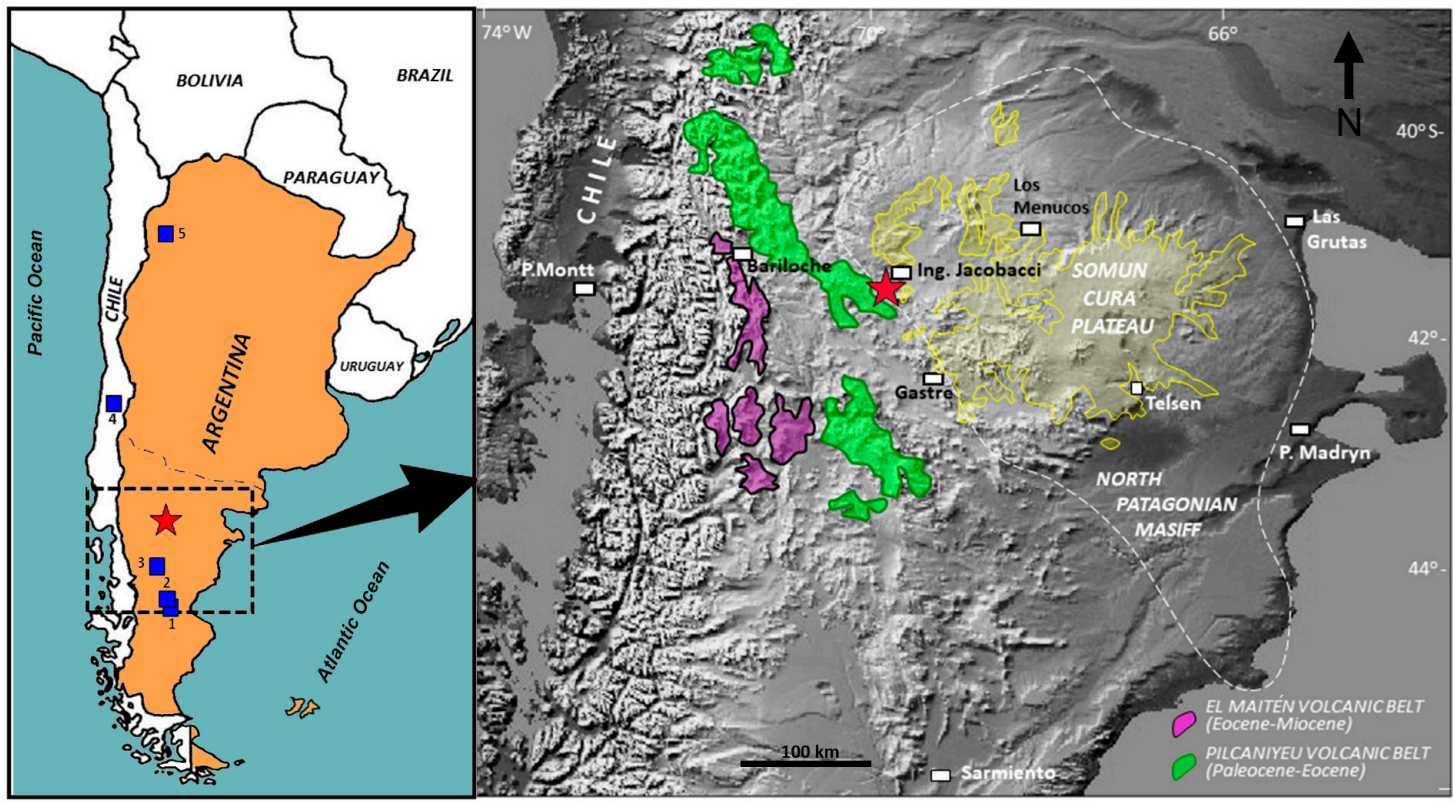

FIG. 1. A. Map of Southern South America showing the main localities discussed in the text. 1. Gran Barranca South of Colhué-Huapi Lake; 2. Cerro del Humo; 3. Gran Hondonada; 4. Tinguiririca; 5. Antofagasta de la Sierra. B. Location of the studied area (red star) in the west margin of the Somun Cura Plateau and adjacent Paleogene volcanic belts in North Patagonia.

Cerro Yeso (Fig. 2). Casamiquela (1963) first reported the occurrence of Paleogene mammals in Cerro Yeso but did not supply precise locality information. Some years later, Casamiquela (1969: 291) indicated that these remains were collected from whitish tuffs of Mustersan or Casamayoran age, bearing "Astraponotus sp. o Albertogaudrya sp., Palaeothentes sp., etcetera", overlaid by pumiceous tuffs of Deseadan or Colhuehuapian age, bearing remains of a leontinid notoungulate. Thus, Casamiquela interpreted that at least two distinct faunal associations occur at Cerro Yeso, based on the taxonomic identifications by R. Pascual and L. Parodi (MLP). The same interpretation was followed by Pascual et al. (1984), who listed Eocene and Oligocene mammals from the Puesto Marileo locality. More recently, González et al. (2000) assigned these sediments to the Las Chacras ("Vulcanitas") Formation, and referred them to the Eocene, partially because of the occurrence of Mustersan and Casamayoran mammals indicated by Casamiquela (1969) and Pascual et al. (1984), although the taxonomic identifications supporting this age was never re-examined.
In October 2017 and April 2018, our team prospected the Cerro Yeso locality, as well as other correlated beds exposed at Chucair farm, $2 \mathrm{~km}$ west of Cerro Yeso (Fig. 2). As a result of these fieldworks, we collected dozens of additional vertebrate remains (mostly mammals). In this contribution, we present an integrative study of the Paleogene volcaniclastic deposits exposed in the area of Ingeniero Jacobacci, in SW Río Negro Province (Argentina), and of the mammals and other vertebrates exhumed from these rocks. We discuss the presumed occurrence of at least two distinct Paleogene faunal associations and its stratigraphic implications with other faunal units in central Patagonia and elsewhere in South America.

\section{Materials and methods}

Twelve of the fossil specimens collected by R. Casamiquela studied here are stored in the Museo Jorge H. Gerhold (Ingeniero Jacobacci); they were included in the original Casamiquela's collection and catalogued under the acronym MJHG_Pa. Other seven specimens are stored in the Museo Argentino de Ciencias Naturales "Bernardino Rivadavia" at 


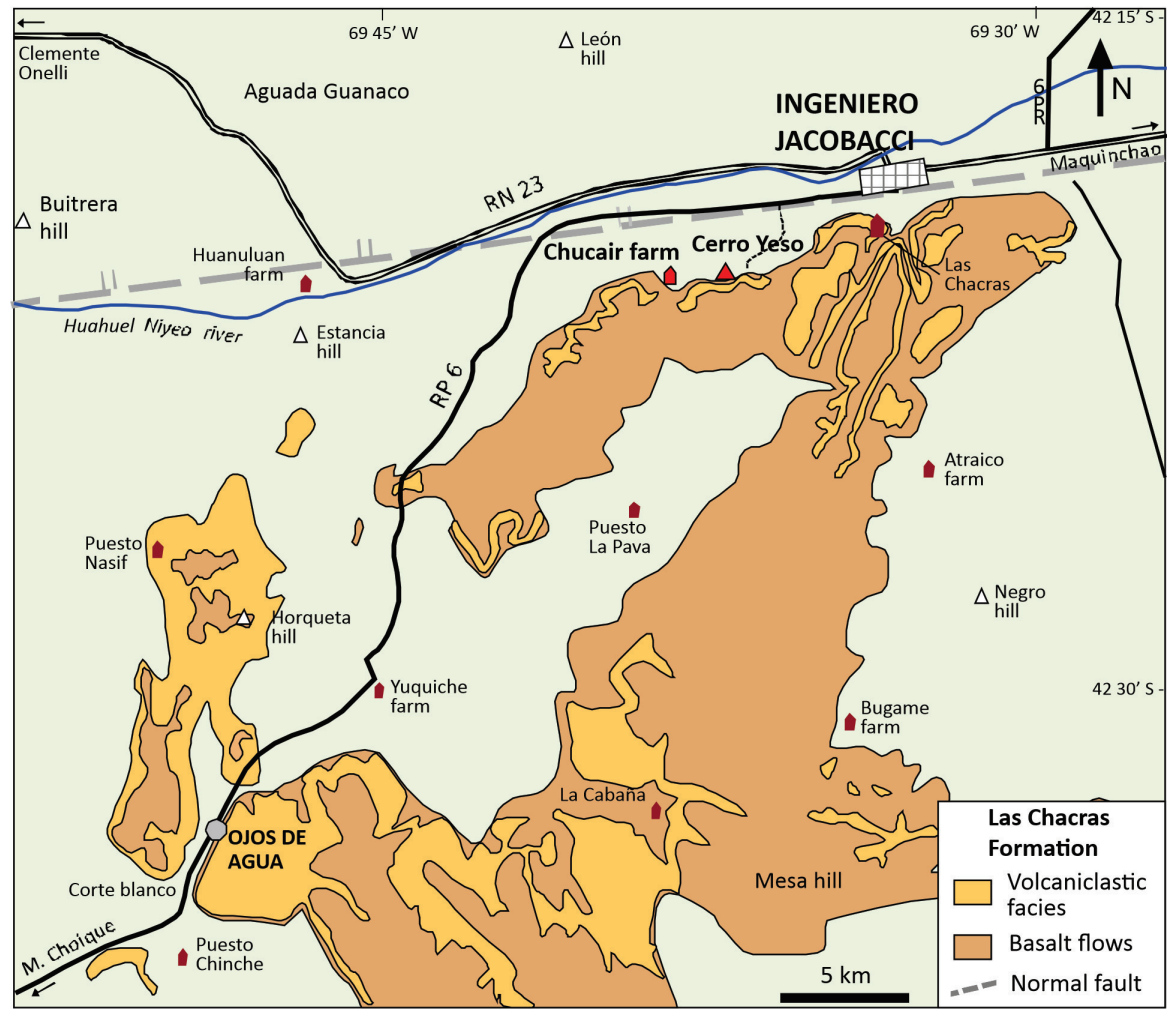

FIG. 2. Distribution of lava flows and volcaniclastic deposits of the Las Chacras Formation at south of Huahuel Niyeo valley (Río Negro, Argentina). See location in figure 1. Modified from Coira (1979) and González et al. (2000).

Buenos Aires (MACN). Fossils collected by our team ( 58 specimens) are also stored in the Museo Jorge H. Gerhold, but are part of a separate collection and catalogued under the acronym MJHG-NCP (New Paleontological Collection). Systematic descriptions, inventory numbers, provenance of the studied fossil specimens, nomenclatorial discussions, and additional figures are provided in Supplementary Information S1. Dental measurements are included in Supplementary Information S2. Taxa between quotation marks indicate the lack of consensus concerning its monophyly.

Institutional abbreviations: MACN: Museo Argentino de Ciencias Naturales "Bernardino Rivadavia" (Buenos Aires, Argentina); MJHG: Museo de Ciencias Naturales, Antropológico e Histórico "Jorge H. Gerhold" (Ingeniero Jacobacci, Río Negro, Argentina); MLP: Museo de La Plata (Argentina).

Anatomical abbreviations: C/c: upper/lower canine; $\mathbf{P} / \mathbf{p}$ : upper/lower premolar; $\mathbf{M} / \mathbf{m}$ : upper/ lower molar.

\section{Geological and stratigraphic setting}

The Las Chacras Formation is a $\sim 80 \mathrm{~m}$ thick succession of volcaniclastic deposits interbedded with lava flows accumulated in the Jacobacci basin (Dalla Salda and Franzese, 1987), at the northwest margin of the Somun Cura Plateau, and adjacent to the North Patagonia volcanic arcs (Fig. 1). This unit is preserved south of the Huahuel Niyeo River, with the best expositions in the area of Ingeniero Jacobacci (Fig. 2), where it lies over the Cretaceous Coli Toro and the Paleogene Huitrera formations (Casamiquela, 1969; González et al., 2000).

The Las Chacras Formation includes two volcaniclastic sections, 34 and $7 \mathrm{~m}$ thick, intercalated with three intervals of basalt flows (Figs. 3, 4A). The volcaniclastic rocks are formed by glass shards and fragments acid to intermediate in composition (Coira, 1979; Coira et al., 1985). They comprise primary and reworked massive tuffs, graded pyroclastic flow deposits composed of poorly-sorted and angular pumice clasts, fine tuff breccias, clast-supported 

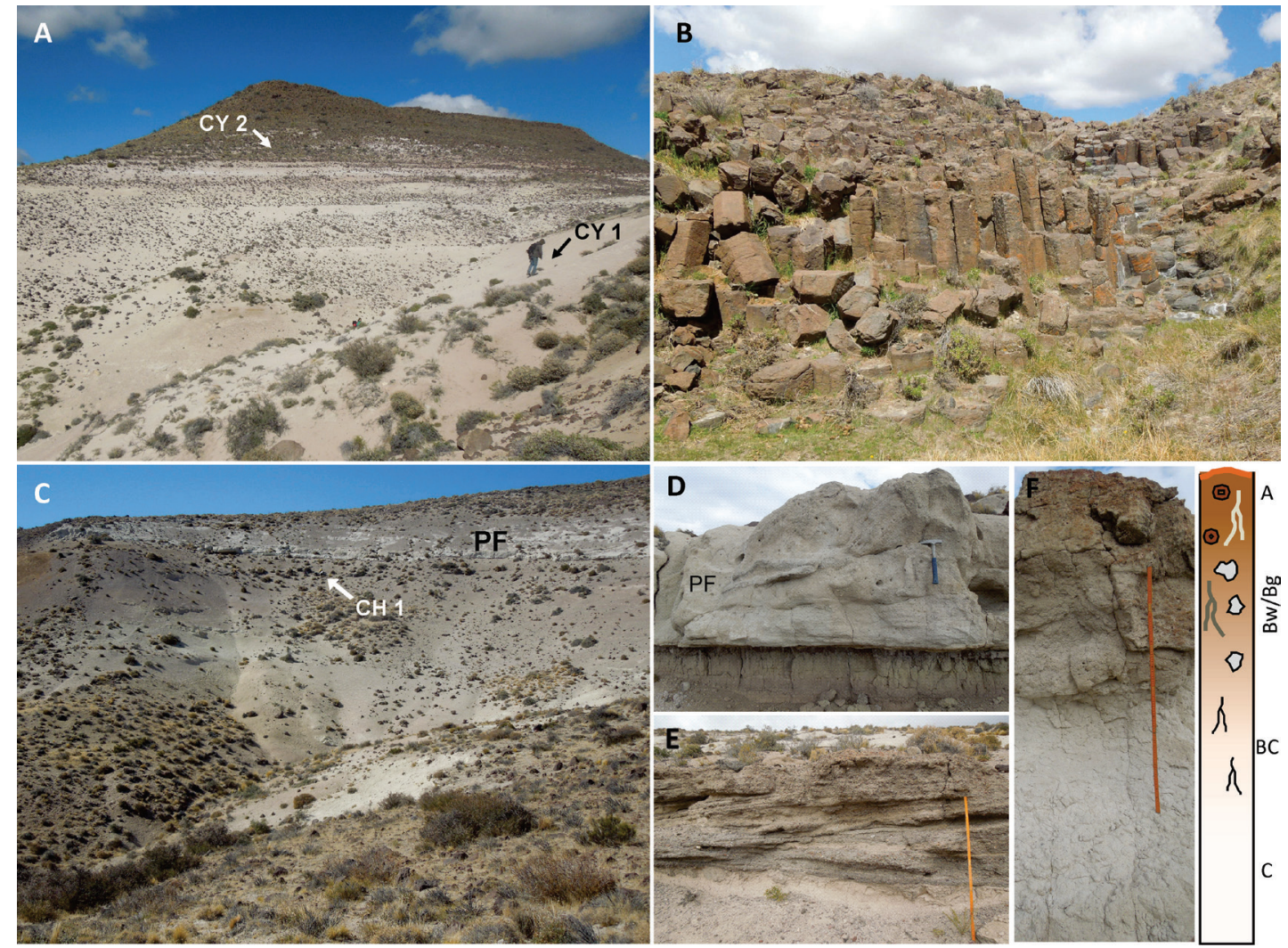

FIG. 3. Studied fossiliferous outcrops of the Las Chacras Formation, west of Ingeniero Jacobacci (Río Negro province). A. Cerro Yeso section showing position of the mammal bearing beds CY 1 and CY 2 (a person at CY 1 for scale). B. Lower basalt with columnar jointing near Puesto Marileo. C. Measured section at Chucair farm showing location of the mammal bearing bed $\mathrm{CH} 1$ and stacked pyroclastic beds (PF). D. Detail of the lower pyroclastic flow with non-erosive, flat basal contact overlying a thin paleosol (hammer $30 \mathrm{~cm}$ ). E. The fossiliferous conglomerate $\mathrm{CH} 1$ showing low angle cross-bedding and erosive lower contact (scale $1 \mathrm{~m}$ ). F. Weakly-developed paleosol exhibiting A horizon with Fe-Mn nodules, Bw or Bg horizon with mottles and drab-haloed rhizoliths, and $\mathrm{BC} / \mathrm{C}$ horizons (scale $1 \mathrm{~m}$ ).

conglomerates, fine to medium sandstones, and intercalated paleosols. Lower basalts (4 m thick) present columnar jointing, while middle (15-20 m thick) and upper basalts ( $\sim \mathrm{m}$ thick) are massive.

The measured profile at Cerro Yeso ( $77 \mathrm{~m}$ thick) corresponds to the lower section (Figs. 3A, 4B) and is bounded by basalt flows at the base and top (Figs. 3B). Few hundred meters NW, this section shows a faulted contact with marine sandstones and claystones of the Upper Cretaceous Coli Toro Formation. The lower part of the profile includes light greenish to yellowish gray, laminated or massive volcaniclastic mudstones, intercalated with fine tuffs. Rhizoliths and fragmentary leaves and stems were also recognized. The middle and upper parts of the profile are composed of fine tuffaceous sandstones showing trough cross-bedding and erosive lower contact, and thinner conglomeratic lenses with pumice fragments and intraformational tuff clasts. These beds intercalate with pinkish gray, very fine, laminated tuffs, and volcaniclastic mudstones. The fossiliferous site CY1 (41'21'51.0”' S 69³7'27.3”'W) occurs $22 \mathrm{~m}$ from the base in a massive volcaniclastic mudstone showing pedogenic features (Fig. 3A). This is the site where Casamiquela collected all his fossils (according to Mr. Marileo, a local farmer who accompanied Casamiquela in his prospections). CY1 also provided the bulk of the mammal remains unearthed by us at Cerro Yeso associated with few anuran remains. The site CY2 occurs in laminated tuffs, $55 \mathrm{~m}$ above the base of the unit in the same profile than CY1 (Fig. 3A), but only produced very few fossil remains. 
A

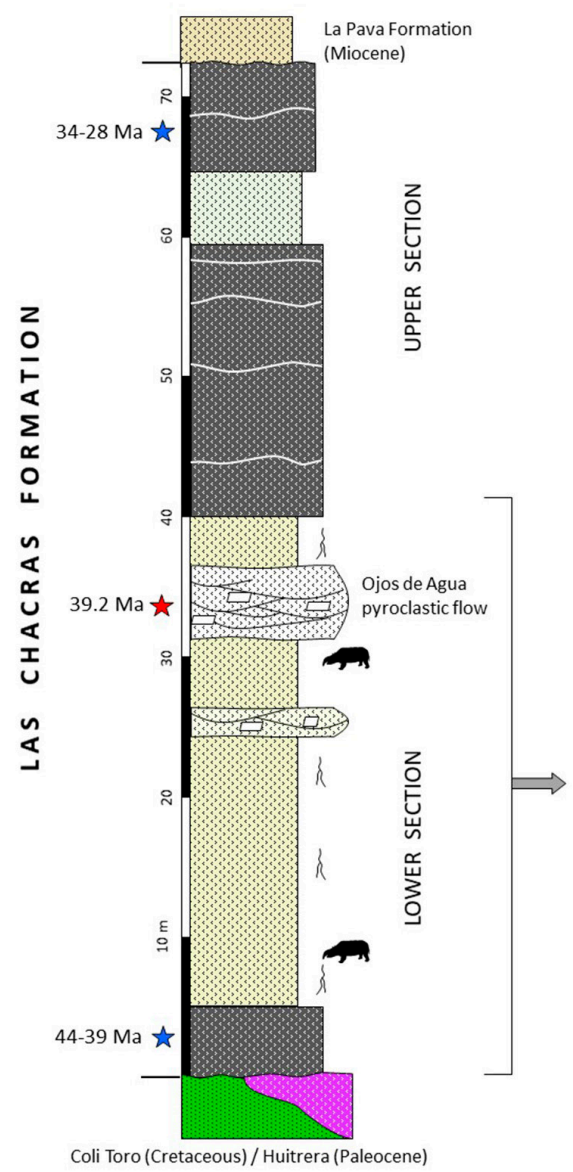

B

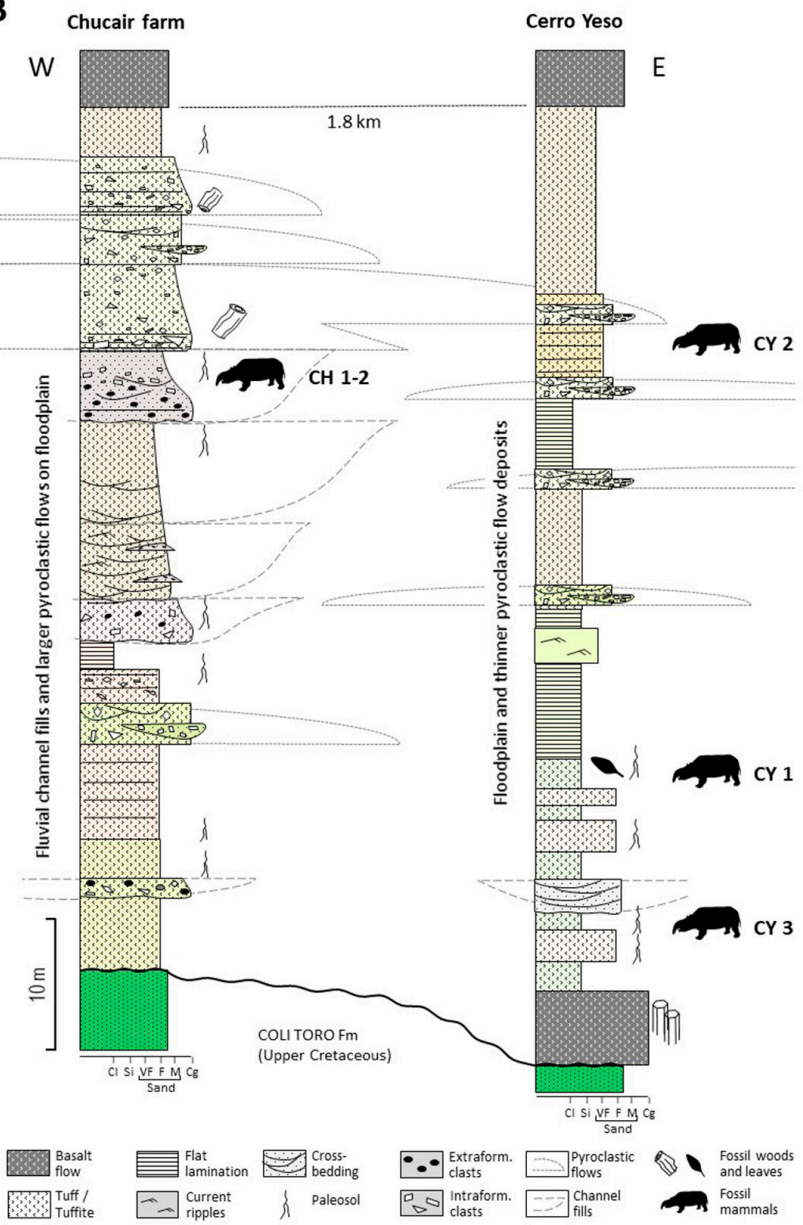

FIG. 4. A. Simplified stratigraphic profile of the Las Chacras Formation at the south margin of the Huahuel Niyeo river, Ingeniero Jacobacci (modified from González et al., 2000). Stars correspond to K-Ar ages. Blue stars after Coira et al. (1985); red star after Mazzoni and Benvenuto (1990). B. Stratigraphic and sedimentologic profiles of the lower section of the Las Chacras Formation bearing Paleogene mammals, at Chucair farm and Cerro Yeso, west of Ingeniero Jacobacci (Río Negro Province).

A third site, CY3 (4121'42.46” S 69³7’38.1” W) preserved several micromammal and scarce anuran remains; it occurs nearly $300 \mathrm{~m}$ west of the measure profile, $11 \mathrm{~m}$ meters above the contact with the Coli Toro Formation, and its stratigraphic position might be slightly lower than CY1 (Fig. 4B).

The profile from Chucair farm presents a similar thickness $(67 \mathrm{~m})$, but shows coarser deposits and more frequent and developed paleosols (Figs. 3C, 4B). The lower contact is on the Coli Toro Formation, and a basalt flow occurs at the top. The lower half consists of yellowish gray to very pale orange, fine-grained tuffs displaying horizontal lamination, small-scale cross-bedding or are massive; fine and massive, thin matrix-supported pyroclastic flow deposits and subordinated volcaniclastic mudstones showing horizontal lamination. The upper half comprises fine, clast-supported conglomerates (Fig. 3E), showing erosive base, through cross-bedding, finning-upward sets and rounded clasts of volcanic rocks. Stacked, whitish pyroclastic flow deposits, up to $13 \mathrm{~m}$ thick are also present (Fig. 3D). They are non-erosive and graded, show cross-bedding or parallel stratification, cut and fill structure, brecciated or deformed zones, and include $0.5-15 \mathrm{~cm}$, angular pumice clasts along with common wood fragments. Paleosols exhibit weak horizonation, fine clayey rhizoliths and rhizohaloes, Fe-Mn nodules, mottles, blocky and 
granular peds, and solitary bee cells (Celliforma isp.) (Fig. 3F). The fossiliferous sites $\mathrm{CH} 1$ (41 ${ }^{\circ} 21^{\prime} 55.3$ " S 69'38'48.9” W) (Figs. 3C, 4B) and CH2 (41 ${ }^{\circ} 22^{\prime}$ ' 12.2" S $69^{\circ} 39^{\prime} 01.3^{\prime \prime} \mathrm{W}$ ) occur in the same clast-supported conglomerate, $45 \mathrm{~m}$ above the base and $3 \mathrm{~m}$ below the major pyroclastic flow of the upper half of the measured section (Figs. 3C, 4B). Both sites are located $\sim 300 \mathrm{~m}$ apart and produced abundant macro and micromammals including the best preserved materials (partial skulls and mandibles) collected by our team.

The continuity of the upper basalt at Cerro Yeso and Chucair farm allows correlating both profiles (Fig. 4B). Differences between them are due to lateral facies changes and bed morphology resulting from differences between fallout, flow (ignimbrite), and subordinated reworked deposits. Volcaniclastic sediments of the Las Chacras Formation were sourced from the Pilcaniyeu-El Maitén volcanic belt system (Fig. 1), and accumulated in a fluvial system next to volcanic edifices. At Cerro Yeso, pyroclastic flow deposits are represented by thin, lenticular and non-erosive bodies. Prevailing well-sorted massive tuffs formed as ash falls, suggest sustained eruptions probably as co-ignimbrite deposits (Lajoie and Stix, 1992). Massive mudstones and tuffs were deposited in vegetated floodplains; which also supported shallow ponds where fine laminated pyroclastic muds accumulated. Paleosols formed in tuffaceous material and showing a very weakly development degree are comparable to vitric Entisols (Soil Survey Staff, 2014). The Chucair section presents coarser deposits, recording gravelly braided channels that reworked tuffaceous floodplains and volcanic clasts. Pyroclastic flow deposits are more frequent and thicker. They show non-erosive, flat and horizontal lower contact (Fig. 3D). Soil forming processes in this area were more intense and modified both fluvial channel and floodplain deposits, but did not affected pyroclastic flows. Pedogenesis produced weakly developed paleosols with typical $\mathrm{A}-\mathrm{Bg} / \mathrm{Bw}-\mathrm{BC} / \mathrm{C}$ profiles, showing numerous gleying features such as rhizohaloes, low-chroma irregular zones (drab mottles) and iron-manganese nodules (Fig. 3F) in surface and subsurface horizons. Volcaniclastic material and dominant redoximorphic attributes of paleosols correspond to aquic Andisols, mostly formed under alternated lapses of reduction (prevailing) and oxidation, associated with water saturation and drying respectively (Soil Survey Staff, 2014). Aquic soil moisture regime is more frequent in areas where ground-water level is shallow. These characteristics are compatible with seasonal subhumid-humid conditions (Retallack, 2001).

\section{Correlations and age}

Volcaniclastic beds from Cerro Yeso and Chucair were previously assigned to the Marileo Member of the Miocene Collon Cura Formation by Coira (1979). This author placed the Eocene mammals reported by Casamiquela (1969) into the Huitrera Formation that is not exposed from this area. Later, Coira et al. (1985) reassigned these deposits to two Paleogene volcanic-sedimentary phases based on new K-Ar dates. The older one (Eocene) comprises rhyolitic-dacitic tuffs bearing the Casamayoran or Mustersan mammals reported by Casamiquela (1969) (see also Pascual et al., 1984), covered by alkaline basalts dated between 44 and $39 \mathrm{Ma}$. The second phase (Oligocene) shows a similar composition with silicic tuffs, presumably preserving the Deseadan mammals reported by Casamiquela (1969), and basalt flows dated at 34-28 Ma (Coira et al., 1985).

Direct and reliable correlation between basalts observed in our profiles and those dated by Coira et al. (1985) in the same area (south margin of Huahuel Niyeo valley) is possible (Fig. 4B). Relative stratigraphic position suggests that the older lava flows (44-39 Ma) recognized by Coira et al. (1985) would correspond to the lower basalts at the base of the Las Chacras Formation, that show similar columnar jointing; while younger lavas (34-28 Ma) would correspond to the uppermost basalts described by González et al. (2000), which are not included in our measured sections (Fig. 4B). Such stratigraphic inferences are also supported by the K-Ar date $(39.2 \pm 2 \mathrm{Ma})$ of a whitish and vitric ignimbrite at Corte Blanco locality, near Ojos de Agua (Mazzoni and Benvenuto, 1990) (Figs. 2, 4A). This ignimbrite was originally attributed to the Ojos de Agua Member of the Pliocene La Cabaña Formation (Nullo, 1978; Coira, 1979), but the absolute age and stratigraphic position discard such assignation (González et al., 2000). Similarity between this ignimbrite and the pyroclastic flow recognized in the Chucair profile (Fig. 4B), particularly the abundance and size of pumice fragments, allow assigning both beds to the Las Chacras Formation. 


\section{Fossil mammals of the lower Las Chacras Formation}

\subsection{Notoungulata}

As in most Paleogene South American vertebrate associations, fossils of notoungulate mammals are abundant and diverse. The most abundant remains belong to maxillary and mandibular fragments with partial dentition and isolated teeth of the small typotherian Pseudhyrax eutrachytheroides (Fig. 5A, B), with protohypsodont cheek teeth, interpreted as the sister taxon of the archaerohyracids, hegetotheriids, and mesotheriids (Billet, 2011). A single specimen (an isolated upper molar) differs from all the Pseudhyrax specimens in being smaller (see Supplementary Information S2) and having comparatively higher crown, more ephemeral enamel lakes and larger mesial and distal bands of exposed dentine (Fig. 5C and Supplementary Information S1, Fig. S1). This specimen is assigned to Eohegetotherium priscum Ameghino, 1901 (=Protarchaeohyrax gracilis, Reguero et al., 2003; see Supplementary Information S1), a more advanced and undisputable archaeohyracid typothere (Billet, 2011). Interatheres are represented by few and fragmentary remains with low crowned teeth (Fig. 5D), likely corresponding to the subfamily Notopithecinae, interpreted by Vera (2016) as a small, middle to late Eocene monophyletic group of early diverging typotherians.
A

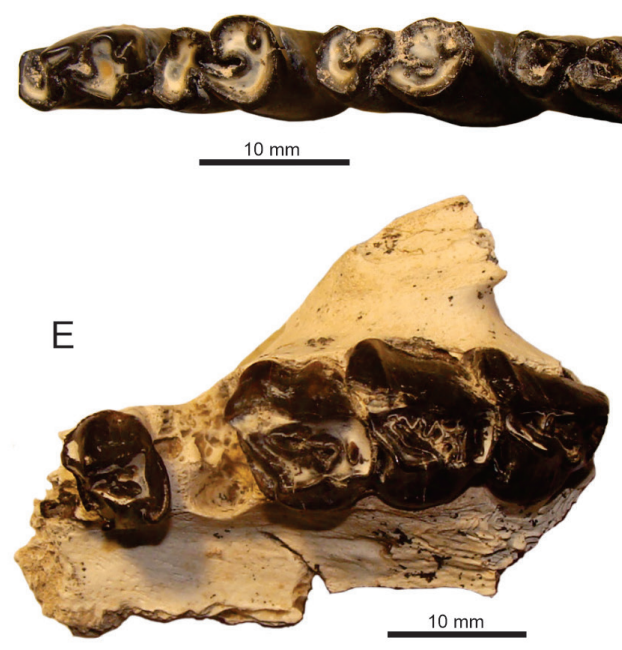

$\mathrm{F}$

G
B

C

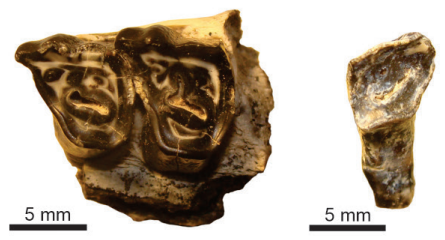

D

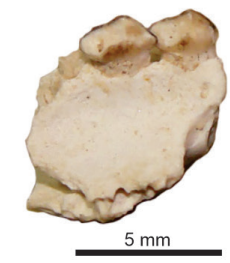

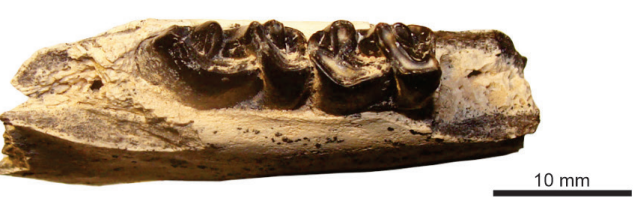
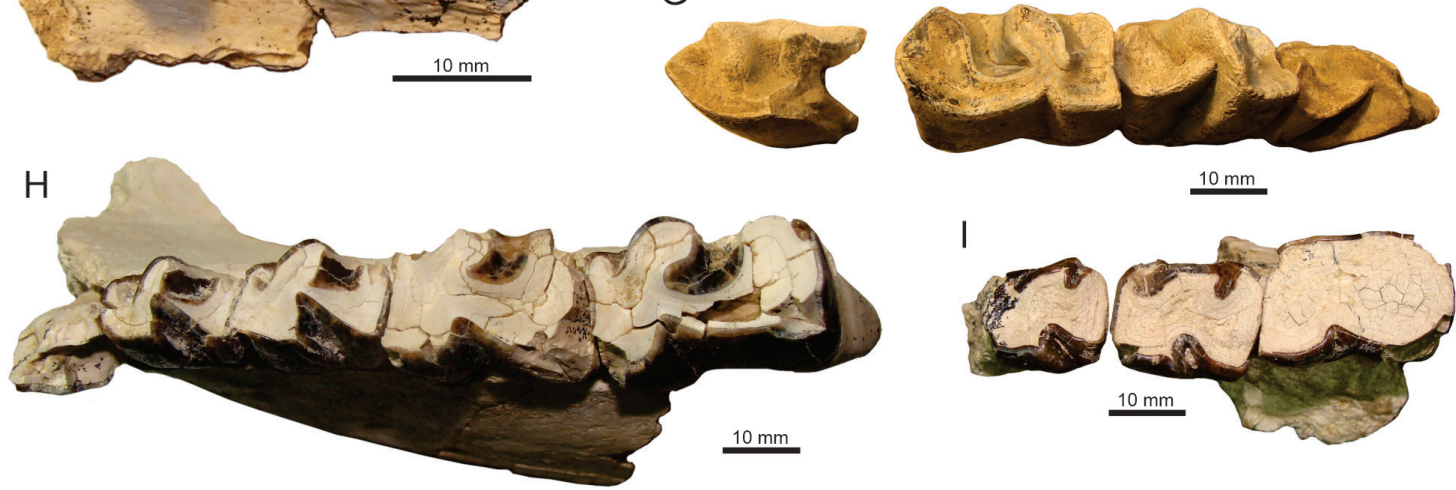

FIG. 5. Notoungulata from Las Chacras Formation. A. MJHG-NCP 255, probably associated left $\mathrm{p} 3$ or p4, and m1-m3 of Pseudhyrax eutrachytheroides. B. MJHG-NCP 8, left maxillary fragment with P4-M1 of Pseudhyrax eutrachytheroides. C. MJHG-NCP 264, isolated right M1 or M2 of Eohegetotherium priscum. D. MJHG-NCP 28, right maxillary fragment with C1-P1 and roots for P2 of Interatheriidae indet. E. MJHG-NCP 2, left maxillary fragment with roots of P4, complete P3, M1-M3 of Puelia sigma. F. MJHG-NCP 5, right mandibular fragment with m2-m3 of Puelia sigma. G. MJHG-NCP 252, associated p3, p4, m1 and partial $\mathrm{m} 2$ or $\mathrm{m} 3$ of ?Periphragnis circunflexus. H. MJHG-NCP 11, partial left mandibular ramus with p2-m2 of Periphragnis palmeri. I. MJHG 148Pa, associated left $\mathrm{p} 3-\mathrm{m} 1$ of Periphragnis sp. 
Toxodontian notoungulates are represented by abundant remains of the basal "notohippid" Puelia sigma (Fig. 5E, F) and at least two species of the isotemnid genus Periphragnis: P. circunflexus (Fig. 5G) and P. palmeri (Fig. 5H), the former being larger sized (see Supplementary Information S2) and without basal cingulids. A specimen with much worn cheek teeth in Casamiquelas's collection (MJHG $148 \mathrm{~Pa}$ ) is catalogued as Leontiniidae. Nevertheless, the lower premolars differ from those of leontiniids in having shorter and simpler talonid, and the lower molars lack the deep lingual flexid between the trigonid and talonid (Fig. 5I) characteristic of the leontiniids (even in worn teeth). Size and morphology of the preserved premolars indicate that MJHG 148Pa belongs unquestionably to an Isotemnidae, and could belong to a third, still undetermined species of Periphragnis.

\subsection{Astrapotheria}

Astrapotheres are the most conspicuous components of the mammal association derived from the Las Chacras Formation. Although less abundant than notoungulates, they are represented by many cranial, mandibular, and dental remains of very large specimens and they are clearly identifiable as belonging to the astrapotheriid genus Astraponotus (Fig. 6A, B, C). The most complete specimen consists of associated right and left mandibular fragments and a maxillary fragment with partial dentition of a juvenile specimen (Fig. 6A) collected by R. Casamiquela in 1953. This specimen is catalogued in the MJHG collection with the number $146 \mathrm{~Pa}$ as belonging to Astraponotus sp. or Albertogaudrya sp., according to identification by R. Pascual (MLP) (in schedula), and almost surely Casamiquela (1969) reported the occurrence of one of these taxa in Cerro Yeso based upon this specimen (see above). In addition, we unearthed a partial skull with complete right upper dental series (Fig. 6B, C) and additional fragmentary dental remains. Three isolated and incomplete vertebrae of a large mammal could also pertain to Astraponotus (whose postcranial skeleton is almost entirely unknown). However, some few isolated dental remains might not belong to Astraponotus, but to a somewhat smaller sized (see Supplementary Information S2) and more advanced taxon (Fig. 6D, E), although they definitively do not match with any known Oligocene astrapothere. A third astrapothere taxon is represented by an isolated upper molar referable to Trigonostylops, much smaller than the formers (see Supplementary Information S2) and with a typical trigonodont pattern (see Simpson, 1967a; MacPhee et al., 2021). The specimen could not be found in MJHG collection, but a drawing was provided by Carbajal et al. (1977; Fig. 1D).

\subsection{Pyrotheria}

Pyrotheres are infrequent in most Paleogene mammal associations. Among large mammals of the Las Chacras Formation, pyrotheres are represented by an isolated tusk (probably lower) (Fig. 6F) and two isolated lower molars with the typical bilophodont pattern of Propyrotherium (Fig. 6G, H), and much more bunodont than in the Oligocene Pyrotherium. We also recovered a lower cheek tooth, doubtfully associated with a tusk fragment. The cheek tooth is not bilophodont, but it has a single, massive, conical cuspid, with a minute distal heel and a crenulated labial? cingulid (see Supplementary Information S1). The latter feature resembles the basal crenulations observed in some cheek teeth of Propyrotherium and Pyrotherium (see Kramarz and Bond, 2014). This tooth might belong to an anterior lower premolar (p2?) of a pyrothere, although its attribution to an astrapothere cannot be discarded.

\subsection{Litopterna}

Among all mammals collected in Cerro Yeso, both by Casamiquela and by us, litopterns are represented by an isolated, very low crowned, and bunolophodont upper cheek tooth (Fig. 7A). Although it displays some "condylarth" appearance, it is more likely a deciduous tooth of an undetermined litoptern (Proterotheriidae?). We also recovered a small mandibular fragment with p3-m1 (Fig. 7B), very likely representing a new member of Adianthidae. Although the dentition of this still little known family shows superficial resemblances with some member of Notopterna (Soria, 1989), adianthids are traditionally referred to Litopterna (Cifelli and Soria, 1983 and references therein), probably allied to the Macraucheniidae (Cifelli, 1993), a position accepted herein.

\subsection{Cingulata}

Cingulates are frequent and diverse in Eocene mammalian assemblages. However, all cingulates 

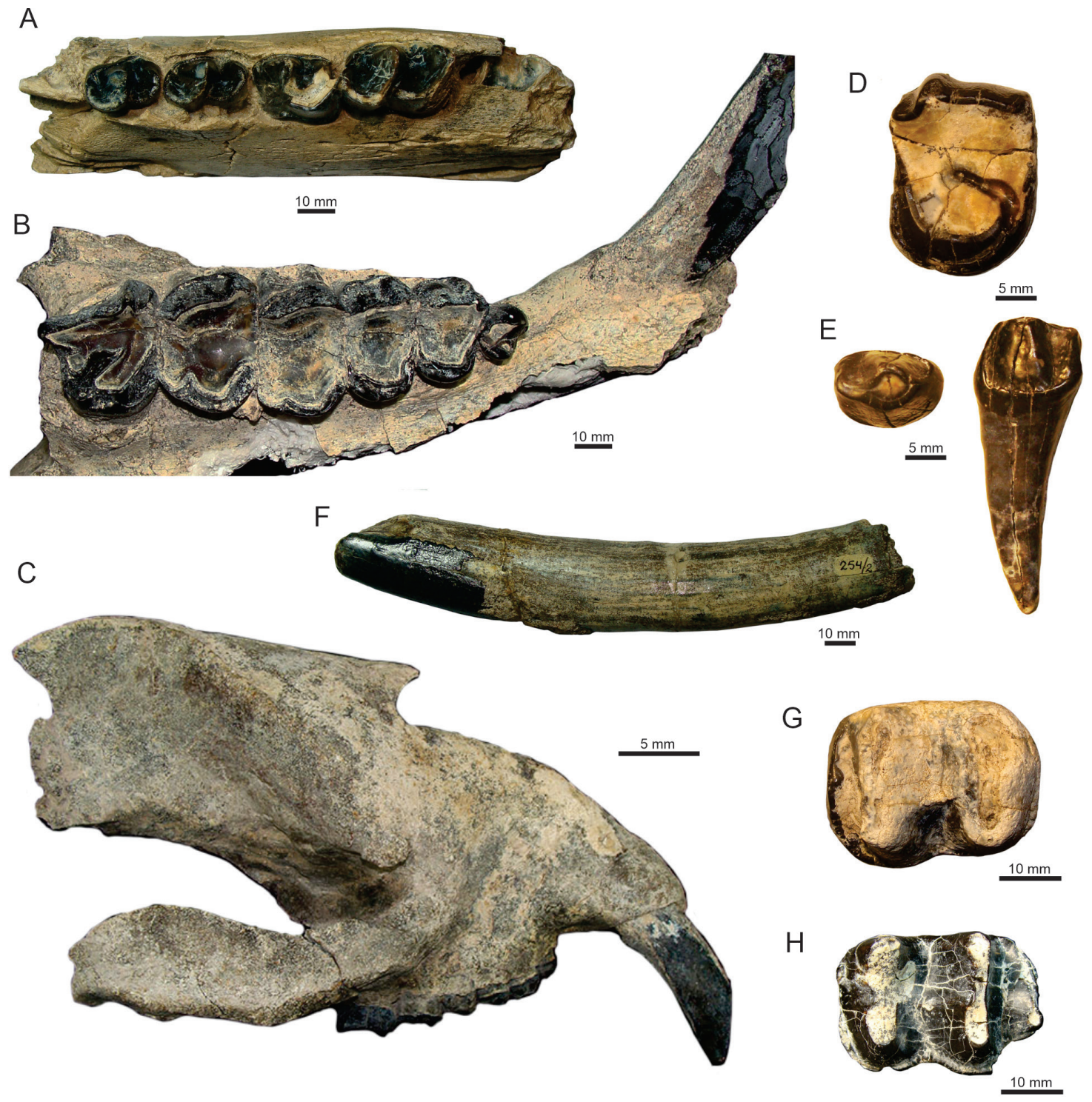

FIG. 6. Astrapotheria and Pyrotheria from Las Chacras Formation. A. MJHG 146Pa, left mandibular fragment with erupting p3-p4, erupted m1-m2 and encrypted m3 of Astraponotus sp. B-C. MJHG-NCP 251, partial skull of Astraponotus sp. B. Right maxillary with complete C1-M3 series. C. Skull in right lateral view. D. MJHG-NCP 269a, right upper premolar (P3?) of cf. Astraponotus. E. MJHG-NCP 269b right lower premolar in occlusal and lingual views cf. Astraponotus. F. MJHG 254Pa, isolated tusk of Propyrotherium saxeum. G. MJHG-NCP 3, isolated right lower molar (m2?) of Propyrotherium saxeum. H. MJHG-NCP 268, isolated left lower molar (m1?) of Propyrotherium saxeum.

in our sample are referable to a single species, Isutaetus depictus Ameghino, 1902, represented by more than a dozen osteoderms, some probably associated. This is a medium-size armadillo with very numerous piliferous foramina on the caudal and lateral margins of the osteoderms (Fig. 7C), evidencing a well-developed piliferous system.

\subsection{Marsupialia}

Sparassodont metatherians are represented by a large mandible with partial dentition (Fig. 7D, E). It is referable to the borhyaenoid Plesiofelis schlosseri by having premolars with reduced distal cingulid, molars with lingual border of the talonid reaching the lingual 
A
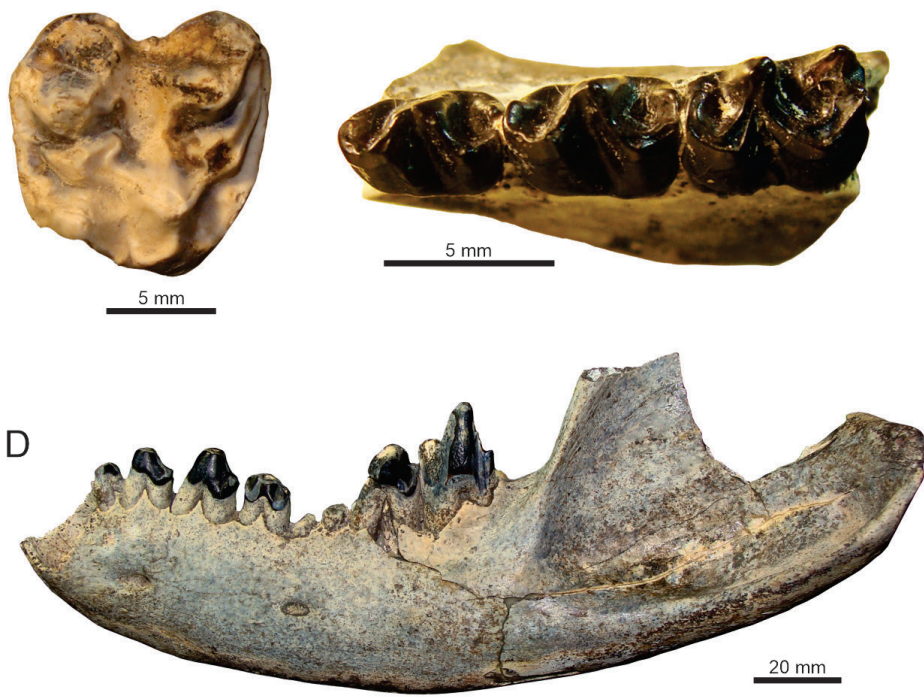

$\mathrm{E}$

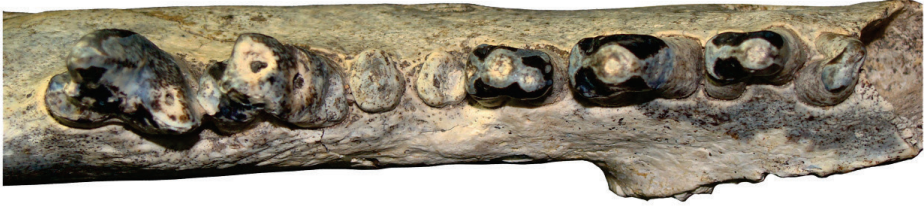

$10 \mathrm{~mm}$
C

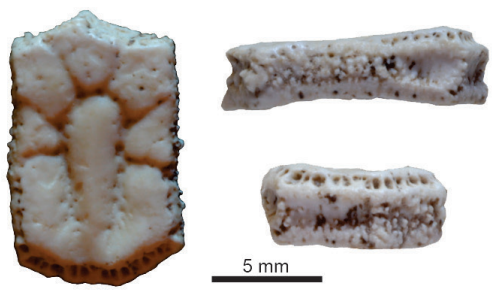

F
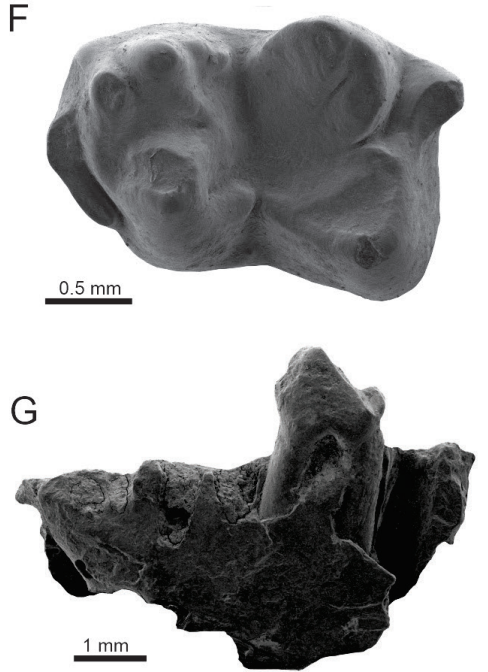

FIG. 7. Litopterna, Cingulata, and Metatheria from Las Chacras Formation. A. MJHG-NCP 256, isolated upper tooth (deciduous?) of Litopterna indet. B. MJHG-NCP 257, left mandibular fragment with p3-m1 of Adianthidae sp. nov. C. MJHG-NCP 26, fixed osteoderm of Isutaetus depictus in external (left), lateral (center), and caudal (right) views. D. MJHG-NCP 58, almost complete left jaw in lateral view of Plesiofelis schlosseri. E. MJHG-NCP 58, left p1- m1, m3-m4, roots of m2, and alveolus for c1 in occlusal view of Plesiofelis schlosseri. F. MJHG-NCP 277, left lower molar (m2?) of Pichipilidae sp. nov? G. MJHG-NCP 278, left mandibular fragment with a premolar (p3?) in lateral view of Pichipilidae sp. nov?

base of the protoconid, cheek teeth with the bulbous roots, among other features (see Supplementary Information S1). This is the only predator recovered to date from the Las Chacras Formation. The body mass in this species has been estimated in $\sim 40 \mathrm{~kg}$ (Prevosti and Forasiepi, 2018), which is on the range of the living jaguar (Panthera onca).

Paucituberculatans are only represented by two, very fragmentary specimens referable to a pichipilid palaeothentoid (Fig. 7F, G), an extinct allied of the living shrew possums Caenolestes, and might belong to a new taxon (see Supplementary Information S1).

\section{Faunal comparisons}

The comparisons among the fossil mammals of the five sites of the Las Chacras Formation prospected herein reveal that the notoungulates Pseudhyrax eutrachytheroides and Puelia sigma, the cingulate Isutaetus depictus, the astrapothere Astraponotus, and the pyrothere Propyrotherium occur both in the lower part of the lower section exposed in $\mathrm{CH} 1$ and $\mathrm{CH} 3$ and in the upper part of the same section in CY1 and CY2 (Figs. 3, 4). The notoungulate Periphragnis is also represented in the lower and upper levels of the studied section, although likely represented by different species. The sparassodont Plesiofelis schlosseri, the Adianthidae gen. et sp. nov., the astrapothere Trigonostylops, and the notoungulate Eohegetotherium priscum are respectively represented by a single specimen and do not allow direct comparisons, as well as those taxa for which we were not able to supply at least a generic identification. Consequently, we find no 
significant differences in taxonomic composition through the studied interval in the lower section of Las Chacras Formation, and we consider all these mammals to represent a single faunal association, herein named the Lower Las Chacras fauna.

Comparing with other Paleogene assemblages (see Table 1), the Lower Las Chacras fauna shares only one genus, Trigonostylops, with the Casamayoran (Vacan and Barrancan) assemblages from central Patagonia. Trigonostylops has a long biochron, spanning throughout almost the entire Eocene (Simpson, 1967a; Kramarz et al., 2019). No specimen collected by Casamiquela or by us is referable to the Casamayoran genus Albertogaudrya, and its possible occurrence alleged by Casamiquela (1969) and Pascual et al. (1984) is almost surely based on specimens unambiguously belonging to Astraponotus.

Most taxa of the Lower Las Chacras fauna are shared with the comparatively more diverse mammal assemblage from the Rosado Member of the Sarmiento Formation at Gran Barranca South of Colhué-Huapi Lake, proposed as the type locality of the Mustersan SALMA (Bond and Deschamps, 2010): Astraponotus, Trigonostylops, Periphragnis, Pseudhyrax eutrachytheroides, and Puelia sigma (Table 1). The same taxa plus Plesiofelis schlosseri are shared with the assemblage from the lower section of the Sarmiento Formation exposed at Gran
Hondonada in central Patagonia (Fig. 1A), assigned to the Mustersan SALMA (Odreman Rivas, 1978; Cladera et al., 2004) (Table 1). Propyrotherium saxeum, Pseudhyrax eutrachytheroides, Astraponotus, and Periphagnis are also shared with the taxonomic grouping derived from the Ameghino's locality Colhué Huapi Norte (Simpson, 1967b) (Table 1). Similarly, the Lower Las Chacras fauna shares with the faunal assemblage described by Roth $(1899,1901$, $1903)$ for his "Cretáceo Superior Lago Musters" Plesiofelis schlosseri, Isutaetus depictus, Pseudhyrax eutrachytheroides, Puelia sigma, and Periphragnis palmeri, in addition to the genera Astraponotus, and Trigonostylops (Table 1). Ameghino's Colhué Huapi Norte and Roth's "Cretáceo Superior Lago Musters" are presumably equivalent to the Mustersan Simpson's (1936) Cerro del Humo Locality (Fig. 1A), although precise stratigraphic origin of these ensembles is still uncertain (see Bond and Deschamps, 2010 and references therein).

The Lower Las Chacras fauna shares only a single taxon (Pseudhyrax) with the still little known, presumable Mustersan fauna of Los Helados derived from the Abanico Formation in central Chile (Engelman et al., 2018). Pseudhyrax, along with Propyrotherium, are also shared with the Mustersan fauna of the middle member of the Geste Formation at Antofagasta de la Sierra, in northwestern Argentina (Fig. 1A) (Babot et al., 2017 and references therein) (Table 1).

TABLE 1. COMPARISON AMONG THE LOWER LAS CHACRAS FAUNAAND OTHER MIDDLE EOCENE-EARLY OLIGOCENE ASSOCIATIONS. ONLY TAXA IDENTIFIED AT GENERIC LEVEL ARE INCLUDED.

\begin{tabular}{|c|c|c|c|c|c|c|c|c|}
\hline \multirow[b]{2}{*}{ Taxon\locality } & \multirow[b]{2}{*}{$\begin{array}{c}\text { Lower } \\
\text { Las } \\
\text { Chacras }\end{array}$} & \multirow{2}{*}{$\begin{array}{c}\text { Casamayoran } \\
\text { Barrancan } \\
\text { (Gran Barranca) } \\
\text { 41.7-39.0 Ma }\end{array}$} & \multicolumn{4}{|c|}{ Mustersan } & \multicolumn{2}{|c|}{ Tinguirirican } \\
\hline & & & $\begin{array}{c}\text { Cerro del Humo } \\
\text { (Colhué Huapi } \\
\text { Norte) }\end{array}$ & $\begin{array}{c}\text { Rosado } \\
\text { (Gran Barranca) } \\
\text { 38.16-37.4 Ma. }\end{array}$ & $\begin{array}{c}\text { Gran } \\
\text { Hondonada }\end{array}$ & $\begin{array}{c}\text { Antofagasta } \\
\text { de la Sierra } \\
\text { 37- } 35 \mathrm{Ma}\end{array}$ & $\begin{array}{c}\text { La Cancha } \\
33.5 \mathrm{Ma}\end{array}$ & $\begin{array}{c}\text { Tinguiririca } \\
\text { 31.6 Ma }\end{array}$ \\
\hline Plesiofelis & $\mathrm{x}$ & - & $\mathrm{x}$ & - & $\mathrm{x}$ & - & - & - \\
\hline Isutaetus & $\mathrm{x}$ & - & $\mathrm{x}$ & - & - & - & - & - \\
\hline Propyrotherium & $\mathrm{x}$ & - & $\mathrm{x}$ & - & - & $\mathrm{x}$ & - & - \\
\hline Trigonostylops & $\mathrm{x}$ & $\mathrm{X}$ & $\mathrm{x}$ & $\mathrm{x}$ & $\mathrm{X}$ & - & - & - \\
\hline Astraponotus & $\mathrm{x}$ & - & $\mathrm{x}$ & $\mathrm{x}$ & $\mathrm{x}$ & - & - & - \\
\hline Pseudhyrax & $\mathrm{x}$ & - & $\mathrm{x}$ & $\mathrm{x}$ & $\mathrm{x}$ & $\mathrm{x}$ & - & $\mathrm{x}$ \\
\hline Eohegetotherium & $\mathrm{X}$ & - & - & - & - & - & $\mathrm{X}$ & $\mathrm{x}$ \\
\hline Puelia & $\mathrm{x}$ & - & $\mathrm{x}$ & $\mathrm{x}$ & $\mathrm{x}$ & - & $\mathrm{x}$ & - \\
\hline Periphragnis & $\mathrm{x}$ & - & $\mathrm{x}$ & $\mathrm{x}$ & $\mathrm{x}$ & - & - & $\mathrm{x}$ \\
\hline
\end{tabular}

Bibliographic sources: Roth (1899, 1901, 1903), Ameghino (1901), Simpson (1936, 1967a, b), Flynn et al. (2003), Reguero et al. (2003), Croft et al. (2003), Cladera et al. (2004), Bond and Deschamps (2010), López et al. (2010), Bradham et al. (2015), Babot et al. (2017). 
Compared with the early Oligocene Tinguiririca fauna of central Chile (type of the Tinguirirican SALMA) (Fig. 1A), the Lower Las Chacras fauna shares only two species, Pseudhyrax eutrachytheroides and Eohegetotherium priscum (Flynn et al., 2003; Reguero et al., 2003), and one genus (Periphragnis) although represented by different species (Bradham et al., 2015). Eohegetotherium priscum and Puelia sigma are the only taxa shared with the early Oligocene La Cancha mammal assemblage at Gran Barranca South of Colhué-Huapi lake in central Patagonia (the Vera Member of the Sarmiento Formation) (Table 1), which is slightly older than the Chilean Tinguirirican fauna (Dunn et al., 2013). These taxa were treated as Protarchaeohyrax gracilis and Puelia plicata respectively (see López et al., 2010; Reguero and Prevosti, 2010).

In sum, the taxonomic composition of the Lower Las Chacras fauna is much closer to the Mustersan assemblages of the Rosado Member and Gran Hondonada than to any known Casamayoran and Tinguirirican assemblages. It should be noted that the Lower Las Chacras fauna does not share any species or genera with late Oligocene and younger faunas elsewhere in South America. The alleged occurrence of Leontiniidae (a typical but not exclusive late Oligocene-early Miocene notoungulate clade), as stated by Casamiquela (1969) and Pascual et al. (1984), is almost surely based on the specimen MJHG 148Pa (Fig. 5I) labeled as Leontiniidae in the MJHG catalogue, after identification of R. Pascual (MLP). As discussed above, this specimen belongs to an undetermined species of the isotemnid Periphragnis, a genus unknown in faunas younger than early Oligocene. Similarly, the alleged presence of the paucituberculate marsupial Palaeothentes in this fauna (Casamiquela, 1969; Pascual et al., 1984) might be based on the specimen MJHG 150Pa, which is the only specimen derived from Cerro Yeso catalogued as belonging to this genus in Casamiquela's collection. The specimen could not be found by us in the MJHG collection, and thus we are unable to confirm the taxonomic identification. Nevertheless, Palaeothentes is only known for Miocene beds (Abello, 2013). Its alleged occurrence in the Lower Las Chacras fauna is clearly incongruent with the geochronologic and faunistic context and might be consequence of an erroneous identification (probably influenced by the fact that Palaeothentes was interpreted in the 60's as oldest known paucituberculate marsupial, when
R. Pascual made the identification). Therefore, we prefer provisionally to omit this taxon from the faunistic list of table 1 until further evidences confirm or reject its record in the Lower Las Chacras fauna.

\section{The age of the Lower Las Chacras fauna}

The proposed stratigraphic correlations and geochronological dates of the Las Chacras Formation indicate that the stratigraphic interval bearing the Lower Las Chacras fauna is younger than the maximum age estimated for the lower basalt flow exposed at Cerro Yeso (44 Ma) (Fig. 4A). This interval is necessarily older than the minimum age obtained for the pyroclasitic flow $3 \mathrm{~m}$ above the fossil bearing conglomerate at Chucair farm $(37.2 \mathrm{Ma})$ (Fig. 4A). This interval would span at most 6.9 $\mathrm{Ma}$, from the Lutetian to the earliest Priabonian, which overlaps the Vacan and Barrancan subages of the Casamayoran SALMA and the Mustersan SALMA (Ré et al., 2010; Dunn et al., 2013). The strong similarity with the Mustersan assemblage from the Rosado Member at Gran Barranca South of Colhué-Huapi Lake, with a well constrained age of 38.16-37.4 Ma (Dunn et al., 2013), suggests that the Lower Las Chacras Formation and its fauna is more likely of late Bartonian or early Priabonian age.

Eohegetotherium is the only element not shared with other Mustersan associations. It exhibits more advanced dental features than Pseudhyrax and was previously considered as an exclusive Oligocene taxon (Reguero et al., 2003). This brings the possibility that the Lower Las Chacras fauna is somewhat younger than the Mustersan Rosado assemblage. However, several Eocene typotheres had a moderately long biochron and coexisted with their morphologically more advanced relatives. For example, Pseudhyrax, traditionally assumed to be typically Mustersan (e.g., Simpson, 1967a; Marshall et al., 1983), also co-occurs with Eohegetotherium in the Tinguiririca fauna (Flynn et al., 2003). García-López et al. (2020) also reported several archaeohyracids with different degrees of hypsodonty coexisting in Eocene units of NW Argentina. Similarly, the interatheriid typothere Eopachyrucos (previously considered as limited to the Oligocene) co-occurs with its less hypsodont relative Guilielmoscottia in the Rosado fauna (Reguero and Prevosti, 2010). These evidences suggest the coexistence of short and long lasting lineages of typotheres instead of successive replacements of short 
lasting lineages, and thus their biochronological value is inconclusive. Since the middle Eocene, the Somun Cura Massif became a high plateau in the retroarc area dividing the extra-Andean Patagonia and would have acted as a permanent topographic, climatic, and selective migration filter for some mammals (Aragón et al., 2011). In this context, the absence of Eohegetotherium in Mustersan assemblages of central Patagonia might be explained by paleobiogeographic rather than chronological differences.

The cingulate Isutaetus depictus, were previously known only from specimens described by Ameghino (1902) as derived from his "couches à Astraponotus" at an unknown locality and a specimen from Roth's (1903) "Cretáceo Superior Lago Musters" locality (Simpson, 1967a; Ciancio and Carlini, 2008). Similarly, the isotemnid Periphragnis palmeri was only known from "Cretáceo Superior Lago Musters" (Roth, 1903), whereas Periphragnis circunflexus only from the "couches à Astraponotus" at an imprecise Colhué-Huapi locality (Ameghino, 1901). These taxa have been traditionally accepted as part of the Mustersan fauna (Simpson, 1948, 1967a), although their stratigraphic origins are dubious and their association with other localities bearing Mustersan mammals (e.g., the Rosado) are still unclear. The Lower Las Chacras fauna documents for the first time the occurrence of these three taxa within a defined faunistic and stratigraphic context and confirms their occurrence in sediments of Mustersan age.

\section{Conclusions}

Las Chacras Formation is a succession of volcaniclastic deposits interbedded with basalt flows accumulated in the Jacobacci basin, at the northwest margin of the Somun Cura Plateau. This succession includes two sedimentary sections: the lower (34 $\mathrm{m}$ thick) was deposited during the middlelate Eocene, the upper ( $7 \mathrm{~m}$ thick) during the early Oligocene. Acid to intermediate tuffs, tuffites (ash fallout deposits), and pumiceous pyroclastic flow deposits accumulated in a fluvial system during an eruptive lapse. Short lapses of ambient stability are recorded in intercalated weakly-developed paleosols, testifying a seasonal subhumid climate.

The analysis presented here of the fossil mammals collected by our team from exposures of the Las Chacras Formation and the re-examination of the specimens unearthed by Casamiquela (1969) revealed that this unit bears a single mammal association (Lower Las Chacras fauna), which is restricted to the lower section of the unit. The occurrence of fossil vertebrates in the upper section is still unknown.

The Lower Las Chacras fauna is composed by at least 16 mammal species corresponding to almost all typical Eocene South American orders (Sparassodonta, Paucituberculata, Cingulata, Astrapotheria, Pyrotheria, Litopterna, and Notoungulata). The notoungulates are the most abundant and diverse, represented by basal members of Toxodontia (i.e., Isotemnidae and Notohippidae) and Typotheria (Archaeohyracidae and Interatheriidae). Other mammal groups, which are diverse in other Eocene associations (e.g., cingulates, litopterns, etc.) seem to be underrepresented in our sample.

The composition of the Lower Las Chacras fauna is much closer to the type Mustersan fauna from the Rosado Member of Gran Barranca South of Colhué-Huapi Lake and to the Mustersan fauna of Gran Hondonada than to any other Paleogene faunal association in Patagonia or elsewhere in South America. It is also similar to the faunal ensemble from Cerro del Humo locality (equivalent to Ameghino's Colhué Huapi Norte and Roth's Cretáceo Superior del Lago Musters), but exact stratigraphic origin of the later is not well determined.

According to isotopic dates of intercalated basalt flows, the stratigraphic interval of the Las Chacras Formation bearing the Lower Las Chacras fauna is geochronologically constrained between 44 and 37.2 Ma. However, the age of the fossiliferous beds would be closer to the younger limit of this interval (i.e., 37.2 Ma) based on biochronological correlation with the Rosado Member (with a constrained age of 38.16-37.4 Ma). Consequently, the lower section of Las Chacras Formation and its fauna is more likely of late Bartonian or early Priabonian age.

Casamiquela (1969) and Pascual et al. (1984) stated that the Paleogene deposits near to Ingeniero Jacobacci also bear Deseadan mammals represented by a leontinid notoungulate. Re-examination of the only specimen in Casamiquela's collection labelled as Leontiniidae revealed that it belongs to an isotemnid (likely Periphragnis), and consequently the Lower Las Chacras fauna bears no known element shared with the Deseadan associations. The presence of the Miocene marsupial Palaeothentes in this fauna alleged by Casamiquela (1969) and Pascual et al. (1984) is unproven. 
The typothere Eohegetotherium priscum is clearly more advanced than its Eocene counterparts and is the only element of the Lower Las Chacras fauna shared with early Oligocene Tinguirirican associations of central Patagonia and Chile but not with Mustersan ones. Likewise, the Lower Las Chacras fauna documents the occurrence of an astrapotheriid (described above as cf. Astraponotus) with more derived dental features than Astraponotus or any other Eocene astrapothere, although in this case there are no undisputable Tinguirirican known astrapothere to compare with. These records suggest that some advanced faunal elements settled in North Patagonia earlier than in central Patagonia. The Somun Cura Massif could have acted as a biogeographic barrier for the southern dispersion of these mammals.

The Lower Las Chacras fauna is the only known Mustersan and the better known Paleogene association for North Patagonia. The Mustersan age is unknown in low latitudes of South America. In middle latitudes, this age is represented only by the roughly coeval fauna of the Geste formation in NW Argentina, which bears a moderately diverse mammalian assemblage. Consequently, the Lower las Chacras Fauna represents a substantial increasing of our knowledge of the Paleogene faunal succession and mammal diversity, not only in Patagonia but also in entire South America.

\section{Acknowledgements}

This paper is a tribute to the pioneering contributions of Rodolfo Casamiquela in the area of Ingeniero Jacobacci. We thank specially to J. Heredia and A. Díaz from the Museo de Ciencias Naturales, Antropológico e Histórico "Jorge H. Gerhold" for their appreciated assistance during our stay at Ingeniero Jacobacci. We also thank Municipalidad de Ingeniero Jacobacci and Secretaría de Cultura de la Provincia de Río Negro for authorizations for fieldworks. To family Marileo and Mr. A. Chucair for allowing access to their farms. To M.V. Sánchez and M. Miñana (MACN) and R.D.E. McPhee (AMNH) for their help during fieldworks. To the reviewer D. García-López for his valuable comments and corrections. This paper is a contribution to the projects PIP 0725 to A.K. and PICT 2017-1265 to E.B.

\section{References}

Abello, M.A. 2013. Analysis of dental homologies and phylogeny of Paucituberculata (Mammalia: Marsupialia). Biological Journal of the Linnean Society 109: 441-465.
Ameghino, F. 1889. Contribución al conocimiento de los mamíferos fósiles de la República Argentina. Actas Academia Nacional de Ciencias en Córdoba 6: 1-1027.

Ameghino, F. 1897. Mammifères crétacés de l'Argentine. Deuxième contribution a la connaissance de la faune mammalogique des couches a Pyrotherium. Boletín Instituto Geográfico Argentino 18: 406-429, 431-521.

Ameghino, F. 1900-1902. L'âge des formations sédimentaires de Patagonie. Anales de la Sociedad Científica Argentina 50: 109-131, 145-165, 209-229; 51: 20-39, 65-91; 52: 198-197, 244-250; 54: 161-180, 220-240, 283-342.

Ameghino, F. 1901. Notices préliminaires sur des ongulés des terrains Crétacés de Patagonie. Boletín de la Academia de Ciencias en Córdoba 16: 349-426.

Ameghino, F. 1902. Notices préliminaires sur des mammifères nouveaux des terrains crètacés de Patagonie. Boletín de la Academia de Ciencias en Córdoba 17: 5-70.

Ameghino, F. 1906. Les Formations sédimentaires du Crétacé supérieur et du Tertiaire de Patagonie. Anales del Museo Nacional de Buenos Aires 8: 1-568.

Aragón, E.; Goin, F.J.; Aguilera, Y.E.; Woodburne, M.O.; Carlini, A.A.; Roggiero, M.F. 2011. Paleogeography and paleoenvironments of northern Patagonia from the Late Cretaceous to the Miocene: the Paleogene Andean gap and the rise of the Northern Patagonian High Plateau. Biological Journal of the Linnean Society 103: 30-315.

Ardolino, A.; Franchi, M.; Remesal, M.; Salani, F. 1999. El volcanismo en la Patagonia extraandina. In Geología Argentina (Caminos, R.; editor). Instituto de Geología y Recursos Minerales: 579-612. Buenos Aires.

Babot, J.; García-López, D.; Deraco, V.; Herrera, C.M.; Del Papa, C. 2017. Mamíferos Paleógenos del subtrópico de Argentina: síntesis de estudios estratigráficos, cronológicos y taxonómicos. In Congreso Geológico Argentino, No. 20, Relatorio, Ciencias de la Tierra y Recursos Naturales del NOA: 730-753. San Miguel de Tucumán.

Bellosi, E. 2010a. Loessic and fluvial sedimentation in Sarmiento Formation pyroclastics, middle Cenozoic of Central Patagonia. In The Paleontology of Gran Barranca: Evolution and Environmental Change through the Middle Cenozoic of Patagonia (Madden, R.; Carlini, A.; Vucetich, M.; Kay, R; editors). Cambridge University Press: 278-292. Cambridge.

Bellosi, E. 2010b. Physical stratigraphy of the Sarmiento Formation (middle Eocene-lower Miocene) at Gran Barranca, central Patagonia. In The Paleontology of Gran Barranca: Evolution and Environmental Change through the Middle Cenozoic of Patagonia (Madden, R.; 
Carlini, A.; Vucetich, M.; Kay, R; editors). Cambridge University Press: 19-31. Cambridge.

Bellosi, E.; Krause, J.M. 2014. Onset of the middle Eocene global cooling and expansion of open-vegetation habitats in central Patagonia. Andean Geology 41 (1): 29-48. doi: 10.5027/andgeoV41n1-a02.

Billet, G. 2011. Phylogeny of the Notoungulata (Mammalia) based on cranial and dental characters. Journal of Systematic Palaeontology 9: 481-497.

Bond, M.; López, G.; Reguero, M. 1997. Rocas Bayas, una localidad fosilífera Paleógena de la Provincia de Río Negro, República Argentina. Ameghiniana 34: p. 533.

Bond, M.; Deschamps, C.M. 2010. The Mustersan Age at Gran Barranca, a review. In The Paleontology of Gran Barranca: Evolution and Environmental Change through the Middle Cenozoic of Patagonia (Madden, R.; Carlini, A.; Vucetich, M.; Kay, R; editors). Cambridge University Press: 255-263. Cambridge.

Bradham, J.; Flynn, J.J.; Croft, D.; Wyss, A. 2015. New Notoungulates (Notostylopidae and Basal Toxodontians) from the Early Oligocene Tinguiririca Fauna of the Andean Main Range, Central Chile. American Museum Novitates 3841: 1-24.

Carbajal, E.; Pascual, R.; Pinedo, R.; Salfity, J.; Vucetich, M.G. 1977. Un nuevo mamífero de la formación Lumbrera (Grupo Salta) de la comarca de Carahuasi (Salta, Argentina). Edad y correlaciones. Publicaciones del Museo Municipal de Ciencias Naturales de Mar del Plata "Galileo Scaglia" 2: 148-163.

Casamiquela, R. 1963. Sobre un par de anuros del Mioceno de Río Negro (Patagonia), Wawelia gerholdi n. gen. n. sp. (Ceratophrydidae) y Gigantobatrachus parodii (Leptodactylidae). Ameghiniana 3: 141-157.

Casamiquela, R. 1969. Historia geológica del Valle del Huahuel Niyeo. Area extrandina del Suroeste de la Provincia de Río Negro, República Argentina (con énfasis en el Pleistoceno). Revista de la Asociación Geológica Argentina 24: 287-329.

Ciancio, M.R.; Carlini, A.A. 2008. Identificación de ejemplares tipo de Dasypodidae (Mammalia, Xenarthra) del Paleógeno de Argentina. Revista del Museo Argentino de Ciencias Naturales 10: 221-237.

Cifelli, R.L. 1993. The phylogeny of the native South American ungulates. In Mammal Phylogeny (Szalay, F.S.; Novacek, M.J.; McKenna, M.C.; editors), Springer-Verlag 2: 195-216. New York.

Cifelli, R.L.; Soria, M.F. 1983. Systematics of the Adianthidae (Litopterna, Mammalia). American Museum Novitates 2771: 1-25.
Cladera, G.; Ruigomez, E.; Ortiz Jaureguizar, E.; Bond, M.; López, G.M. 2004. Tafonomía de La Gran Hondonada (Formación Sarmiento, edad-mamífero Mustersense, Eoceno Medio) Chubut, Argentina. Ameghiniana 41: 315-330.

Coira, B. 1979. Descripción Geológica de la Hoja 40 d, Ingeniero Jacobacci, Provincia de Río Negro, Carta Geológico-Económica de la República Argentina, escala 1:200.000. Servicio Geológico Nacional, Boletín 168: 1-101.

Coira, B.; Franchi, M.; Nullo, F.E. 1985. Vulcanismo Terciario al oeste de Somuncura y su relación con el arco magmático de la Cordillera Norpatagónica, Argentina. In Congreso Geológico Chileno, No. 4, Actas 3: 68-88. Antofagasta.

Croft, D.; Bond, M.; Flynn, J.J.; Reguero, M.; Wyss, A. 2003. Large Archaeohyracids (Typotheria, Notoungulata) from Central Chile and Patagonia, Including a Revision of Archaeotypotherium. Fieldiana Geology, New Series 49: 1-38.

Dalla Salda, L.; Franzese, J. 1987. Las megaestructuras del Macizo y Cordillera Norpatagónica Argentina y la génesis de las cuencas volcano-sedimentarias Terciarias. Revista Geológica de Chile 31: 3-13. doi: 10.5027/andgeoV14n2-a01.

Dunn, R.; Madden, R.; Kohn, M.; Schmitz, M.; Strömberg, C.; Carlini, A.; Ré, G.; Crowley, J. 2013. A new high precision $\mathrm{U}-\mathrm{Pb}$ chronology for middle Eocene-early Miocene South American Land Mammal Ages of the Sarmiento Formation, Gran Barranca, Chubut Province, Argentina. Geological Society of America, Bulletin 125: 539-555.

Engelman, R.K.; Flynn, J.J.; Gans, P.; Wyss, A.R.; Croft, D.A. 2018. Chlorocyon phantasma, a late Eocene borhyaenoid (Mammalia: Metatheria: Sparassodonta) from the Los Helados locality, Andean Main Range, Central Chile. American Museum Novitates 3918: 1-22.

Feruglio, E. 1949. Descripción geológica de la Patagonia, Vol. 2. Dirección General de Yacimientos Petrolíferos Fiscales: 349 p. Buenos Aires.

Flynn, J.J.; Wyss, A.R.; Croft, D.A.; Charrier, R. 2003. The Tinguiririca Fauna, Chile: biochronology, paleoecology, biogeography, and a new earliest Oligocene South American Land Mammal “Age”. Palaeogeography, Palaeoclimatology, Palaeoecology 195: 229-259.

Franchi M.; Nullo, F.; Sepúlveda, E.; Uliana, M. 1984. Las sedimentitas terciarias. In Congreso Geológico Argentino, No. 9, Geología y Recursos Naturales de la provincia de Río Negro, Relatorio: 215-266. Bariloche. 
García-López, D.A.; Gelfo, N.F.; Scanferla, A.; Babot, J.; Ferro, A.; Saade, L.S. 2020. The pre-Oligocene diversity of hypsodont typotherians (Mammalia, Notoungulata) in Northwestern Argentina. Ameghiniana 57: 117-131.

González, P.; Dalponte, M.; Coluccia, A.; Franchi, M.; Caba, R. 2000. Hoja Geológica 4169-III Ingeniero Jacobacci, Provincia de Río Negro. Servicio Geológico Minero Argentino. Instituto de Geología y Recursos Minerales. Boletín 311:1-97. Buenos Aires,

Kraglievich, J.L. 1957. Sobre la presencia de Carolozittelia cf. tapiroides Ameghino en la Fm. La Balsa de Neuquén. Ameghiniana 1: 22-26.

Kramarz, A.G.; Bond, M. 2014. Reconstruction of the dentition of Propyrotherium Ameghino, 1901 (Mammalia, Pyrotheria). Taxonomic and phylogenetic implications. Journal of Vertebrate Paleontology 34: 434-443.

Kramarz, A.G.; Forasiepi, A.; Bond, M. 2011. Vertebrados Cenozoicos. In Geología y recursos naturales de la provincia del Neuquén (Leanza, H.A.; Arregui, C.; Carbone, O.; Danieli, J.C.; Vallés, J.M.; editors). Congreso Geológico Argentino No. 18, Relatorio: 557-572. Neuquén.

Kramarz, A.G.; Bond. M.; Carlini, F. 2019. Astrapotheres from Cañadón Vaca, middle Eocene of central Patagonia. New insights on diversity, anatomy, and early evolution of Astrapotheria. Paleontologia Electronica 22.2.52A: 1-22. doi: 10.26879/986.

Lajoie, J.; Stix, J. 1992. Volcaniclastic rocks. In Facies Models: Response to Sea Levels Changes (Walker, R.G.; James, N.P.; editors). Geological Association of Canada: 101-118. Ontario.

López, M.G.; Ribeiro, A.M.; Bond, M. 2010. The Notohippidae (Mammalia, Notoungulata) from Gran Barranca: Preliminary Considerations. In The Paleontology of Gran Barranca: Evolution and Environmental Change through the Middle Cenozoic of Patagonia (Madden, R.; Carlini, A.; Vucetich, M.; Kay, R;. editors). Cambridge University Press: 143151. Cambridge.

MacPhee, R.D.E.; Hernández del Pino, S.; Kramarz, A.; Forasiepi, A.M.; Bond, M.; Sulser, R.B. 2021. Cranial morphology and phylogenetic relationships of Trigonostylops wortmani, an Eocene South American native ungulate. Bulletin of the American Museum of Natural History 449: 1-183.

Marshall, L.G.; Hoffstetter, R.; Pascual, R. 1983. Mammals and stratigraphy: geochronology of continental mammals-bearing Tertiary of South America. Paleovertebrata, Mémoire Extraordinaire: 1-93.
Mazzoni, M. 1985. La Formación Sarmiento y el vulcanismo paleógeno. Revista de la Asociación Geológica Argentina 40: 60-68.

Mazzoni, M.; Benvenuto, A. 1990. Radimetric ages of Tertiary ignimbrites and the Collon Cura Formation, Northwestern Patagonia. In Congreso Geológico Argentino, No. 11, Actas: 87-90. San Juan.

Nullo, F.E. 1978. Descripción geológica de la Hoja 41d. Lipetrén. Boletín del Servicio Geológico Nacional 158: 1-968.

Odreman Rivas, O.E. 1978. Sobre la presencia de un Polydolopidae (Mammalia, Marsupialia) en capas de Edad Mustersense (Eoceno Medio) de Patagonia. Obra del Centenario del Museo de La Plata 5: 29-38.

Pascual, R.; Ortega Hinojosa, E.J.; Gondar, D.; Tonni, E. 1965. Las edades del Cenozoico mamalífero de la Argentina, con especial atención a aquellas del territorio bonarense. Anales de la Comisión de Investigación Científica 6: 165-193. Buenos Aires.

Pascual, R.; Bondesio, P.; Vucetich, M.G.; Scillato-Yané, G.J.; Bond, M.; Tonni, E.P. 1984. Vertebrados fósiles cenozoicos. In Congreso Geológico Argentino, No. 19, Relatorio 2: 439-461. Bariloche.

Prevosti, F.J.; Forasiepi, A.M. 2018. Evolution of South American mammalian predators during the Cenozoic: Paleobiogeographic and paleoenvironmental contingencies. Springer: 196 p. Dordrecht.

Ré, G.H.; Bellosi, E.S.; Heizler, M.; Vilas, J.F.; Madden, R.H.; Carlini, A.A.; Kay, R.F.; Vucetich, M.G. 2010. A geochronology for the Sarmiento Formation at gran Barranca. In The Paleontology of Gran Barranca: Evolution and Environmental Change through the Middle Cenozoic of Patagonia (Madden, R.; Carlini, A.; Vucetich, M.; Kay, R.; editors), Cambridge University Press: 46-59. Cambridge.

Reguero, M.A.; Prevosti, F.J. 2010. Rodent-like notoungulates (Typotheria) from Gran Barranca, Chubut Province, Argentina: phylogeny and systematic. In The Paleontology of Gran Barranca: Evolution and Environmental Change through the Middle Cenozoic of Patagonia (Madden, R.; Carlini, A.; Vucetich, M.; Kay, R; editors). Cambridge University Press: 152-169. Cambridge.

Reguero, M.A.; Croft, D.A.; Flynn, J.J.; Wyss, A.R. 2003. Small Archaeohyracids (Typotheria, Notoungulata) from Chubut Province, Argentina, and Central Chile: Implications for Trans-Andean Temporal Correlation. Fieldiana, Geology New Series 48: 1-18

Retallack, G.J. 2001. Soils of the past: an introduction to Paleopedology. $2^{\text {nd }}$ ed. Blackwell: 404 p. Oxford. 
Roth, S. 1899. Aviso preliminar sobre mamíferos mesozoicos encontrados en Patagonia. Revista del Museo de La Plata 9: 381-388.

Roth, S. 1901. Notas sobre algunos nuevos mamíferos fósiles. Revista del Museo de La Plata 10: 252-256.

Roth, S. 1903. Noticias sobre nuevos mamíferos fósiles del Cretáceo Superior y Terciario de la Patagonia. Revista del Museo de La Plata 11: 133-158.

Simpson, G.G. 1936. Notas sobre los Mamíferos más antiguos de la Colección Roth. Instituto del Museo de la Universidad Nacional de La Plata, Obra del Cincuentenario 2: 63-94.

Simpson, G.G. 1940. Review of the mammal-bearing Tertiary of South America. Proceedings of the American Philosophy Society 83: 649-709.

Simpson, G.G. 1948. The beginning of the Age of Mammals in South America. Part 1. Introduction. Systematics: Marsupialia, Edentata, Condylarthra, Litopterna and
Notioprogonia. Bulletin of the American Museum of Natural History 91: 1-232.

Simpson, G.G. 1967a. The beginning of the Age of mammals in South America. Part 2. Bulletin of the American Museum of Natural History 137: 1-259.

Simpson, G.G. 1967b. The Ameghino's localities for early Cenozoic mammals in Patagonia. Bulletin of the Museum of Comparative Zoology 136 (4): 63-76.

Soil Survey Staff. 2014. Keys to Soil Taxonomy. $12^{\text {th }}$ ed. United States Department of Agriculture. Natural Resources Conservation Services: 362 p. Washington, DC. Soria, M.F. 1989. Notopterna: un nuevo orden de mamíferos ungulados eógenos de América del Sur. Parte I. Los Amilnedwardsidae. Ameghiniana 25: 245-258.

Vera, B. 2016. Phylogenetic revision of the South American notopithecines (Mammalia: Notoungulata). Journal of Systematic Palaeontology 14: 461-480. doi:10.1080 /14772019.2015.1066454.

Manuscript received: August 09, 2021; revised/accepted: November 24, 2021; available online: January 31, 2022. 


\title{
Supplemetary Information S1
}

In this Supplementary Information, we provided additional descriptions of the mammal remains from the Lower Las Chacras Formation and comparison with related mammals from other Paleogene associations. We focused on characters supporting the taxonomic identifications and features representing new anatomical information. We also provided taxonomic and nomenclatorial discussion for taxa with controversial status. Citations to figures 5, 6, and 7 correspond to the figures included in the main text. Figure S1 is provided at the end of this supplement.

Institutional abbreviations: AMNH: American Museum of Natural History (New York, USA); MACN: Museo Argentino de Ciencias Naturales "Bernardino Rivadavia" (Buenos Aires, Argentina); MJHG: Museo de Ciencias Naturales, Antropológico e Histórico "Jorge H. Gerhold” (Ingeniero Jacobacci, Río Negro, Argentina); MLP: Museo de La Plata (Argentina); MPEF: Museo Paleontológico Egidio Feruglio (Trelew, Argentina); SGOPV: Museo de Historia Natural, Paleontología de Vertebrados (Santiago de Chile, Chile).

Anatomical abbreviations: C/c: upper/lower canine; P/p: upper/lower premolar; M/m: upper/lower molar. Localities abbreviations: CY1: Cerro Yeso site 1; CY2: Cerro Yeso site 2; CY3: Cerro Yeso site 3; CH1: Chucair farm site 1; CH2: Chucair farm site 2. See main text for stratigraphic position of the fossil localities.

Systematic paleontology

\author{
Class Mammalia Linnaeus, 1758 \\ Subclass Metatheria Huxley, 1880 \\ Order Sparassodonta Ameghino, 1894 \\ Family Borhyaenidae Ameghino, 1894 \\ Genus Plesiofelis Roth, 1903
}

Type species. Plesiofelis schlosseri Roth, 1903

Distribution. Mustersan SALMA (late middle Eocene); Chubut and Río Negro provinces, Argentina (Simpson, 1967; Marshall, 1978; Cladera et al., 2004; this work).

\section{Plesiofelis schlosseri Roth, 1903 \\ Figs. 7D, E; S1 A}

Referred specimens and provenance. MJHG-NCP 58, almost complete left jaw with alveolus for c1, p1-p3, $\mathrm{m} 1$, roots of $\mathrm{m} 2$, and $\mathrm{m} 3-\mathrm{m} 4(\mathrm{CH} 1)$.

Descriptions and comparisons. MJHG-NCP 58 preserves most of the postcanines teeth, almost complete horizontal ramus, the condyle, and part of the ascending ramus. It is the most complete specimen of this genus known so far and provides new morphological information for the taxon. Comparing with other basal borhyaenoids, the size of MJHG-NCP 58 is very similar to the holotype of P. schlosseri (MLP 11-114) falling within the range of Pharsophorus lacerans (holotype, MACN A 52-391), and larger than Chlorocyon phantasma (holotype SGOPV 6200, Engelman et al., 2018). The horizontal ramus is robust and high. The depth at $\mathrm{m} 4 / \mathrm{m} 1-\mathrm{m} 4$ length ratio is 0.776 (measured on the lingual side), very similar to the holotype of P. schlosseri (0.78) and Pharsophorus lacerans (0.77) and proportionally taller than in C. phantasma (0.66, see Engelman et al., 2018). The ventral border is markedly curved, similar to the holotype of $P$. schlosseri (after interpretation of Cabrera [1927: fig 1]) and to the specimen MPEF-PV 4190 tentatively referred to Ph. lacerans (Goin et al., 2010: fig. 6.1), and differing from the straighter ventral border seen in the holotype of Pharsophorus lacerans, Ph. tenax (Marshall, 1978: fig 5), and Chlorocyon phantasma (Engelman et al., 2018). The symphysis in MJHG-NCP 58 extends back to the level of the distal root of p3, nearly as in the holotype of $P$. schlosseri and in Pharsophorus lacerans (in C. phantasma it probably extends only slightly 
caudal to p2, following Engelman et al., 2018). The symphysis of MJHG-NCP 58 is rugose, suggesting that it was connected by ligaments at life (not tightly ossified as in some large-sized Miocene borhyaenids and "proborhyaenids" (Babot et al., 2002). In labial view, there are two mental foramina of similar size, as in the specimen tentatively referred to Ph. lacerans MPEF-PV 4190 by Goin et al. (2010) but differing from the holotype of $P h$. lacerans and Ph. tenax (Marshall, 1978: fig. 5) with more than two mental foramina (by damage this feature is unknown in the holotype of P. schlosseri). The rostralmost mental foramen in MJHG-NCP 58 opens at the level of distal root of $\mathrm{p} 2$, while the caudal one does at the level of the mesial root of $\mathrm{m} 2$. The coronoid process rises with an angle of $\sim 70^{\circ}$ (defined between the alveolar line and the anterior coronoid crest). The mandibular foramen opens about the level of the midpoint of the coronoid process. The condyle sets about the level of the tooth row; it is slightly dorsal to the alveolar border in C. phantasma, according to Engelman et al. (2018), whereas it is dorsal to the alveolar border in the specimen tentatively referred to Ph. lacerans MPEF-PV 4190 (Goin et al., 2010: fig, 6.1).

The teeth have robust and bulbous roots, even more than in holotype of $P$. schlosseri (especially on $\mathrm{p} 3$ ), but clearly differing from Ph. lacerans and C. phantasma with non-bulbous roots (Fig. S1 A). In MJHG-NCP 58 there is no diastema between premolars, similar to the holotype of P. schlosseri and Ph. lacerans, and in contrast to C. phantasma with diastemata between c-p1-p2 and possibly p2-p3 (Engelman et al., 2018). The p1 is implanted oblique respect the tooth row; the distal root is the largest and is placed slightly lingual to the mesial root of p2. According to Marshall (1978), Pharsophorus has oblique p1 whereas in Plesiofelis the $\mathrm{p} 1$ is in line with the tooth row as diagnostic features. However, the holotype of $P$. schlosseri does not preserve the $\mathrm{p} 1$ but only a part of the alveolus of the distal root, which is slightly displaced lingually respect to the tooth row; some degree of obliquity of $\mathrm{p} 1$ cannot be discarded. Consequently, the diagnostic value of this character is questionable. In MJHG-NCP 58, there is a marked increasing in size from p1 to p3. In C. phantasma premolars increase more gradually (Engelman et al., 2018), whereas in Pharsophorus, the last premolar is proportionally larger. Both $\mathrm{p} 2$ and $\mathrm{p} 3$ of MJHG-NCP 58 (p1 is largely damaged) have a main cusp followed by a distal cingulid or heel bearing a small cusp (Fig. S1 A), as in the holotype of P. schlosseri. The distal heel of premolars is larger in Ph. lacerans (Marshall, 1978; Patterson and Marshall, 1978), and the p3 is not erected but markedly inclined to $\mathrm{m} 1$ (Fig. S1 A), a feature traditionally interpreted as diagnostic of Pharsophorus (e.g., Marshall, 1978; Patterson and Marshall, 1978). However, different degree of inclination of p3 has been also reported for other borhyaenoids (Forasiepi et al., 2015; Engelman et al., 2018). The molars of MJHG-NCP 58 are damaged and worn out; they increase rapidly in size towards $\mathrm{m} 4$. The much worn $\mathrm{m} 1$ is interpreted as having three, nearly aligned cuspids: the paraconid, the protoconid (which was the largest according to the base preserved), and a tall talonid cuspid, and there is no trace of metaconid since no cusp is associated to the distal wall of the protoconid (present in posterior molars). This architecture of $\mathrm{m} 1$ largely resembles the holotype of $P$. schlosseri, MLP 11-114 with a tall talonid cusp (=hypoconid). In Ph. lacerans, as seen in its holotype, the talonids bear cusps of smaller size (Marshall, 1978; Patterson and Marshall, 1978; Forasiepi et al., 2015). In MJHG-NCP 58 there is a broad anterobasal cingulid with a small cingular cuspid. In the holotype of $P$. schlosseri, the presence of a similar cuspid on $\mathrm{m} 1$ is uncertain (as well as on $\mathrm{m} 4$ ), but is present on $\mathrm{m} 2$ and $\mathrm{m} 3$. In MLP 11-115, referred to P. schlosseri, the $\mathrm{m} 4$ (the only preserved tooth) also shows an anterobasal cingular cuspid. However, this character was interpreted as variable and with dubious taxonomic value (see discussion in Cabrera, 1927; Marshall, 1978). The $\mathrm{m} 1$ talonid is largely worn in MJHG-NCP 58, but apparently was somewhat smaller (shorter and narrower) than in the holotype of P. schlosseri. The lingual border of the talonid wraps around the lingual base of the protoconid (Fig. S1 A), strongly resembling the lingual cingular shelf seen in P. schlosseri (see also Marshall, 1978; Patterson and Marshall, 1978; Goin et al., 2007), but differing from Ph. lacerans MACN A 52-391 in which the lingual border of the talonid ends at the distal face of the protoconid. There is a wide postcingulid defining a lobe of enamel over the distolabial face of the distal root, as in Paleogene borhyaenids and other borhyeanoids. The $\mathrm{m} 2$ in MJHG-NCP 58 is broken at the level of the roots. Likely, this was a breakage occurring in life since the alveolar border of the dentary is partially retracted. The $\mathrm{m} 3-\mathrm{m} 4$, although partially preserved, show a dominant cusp, the protoconid, a tall paraconid mesio-lingually to the protoconid, and a rudimentary metaconid rising from the distolingual face of the protoconid (Fig. S1 A). The talonids are damaged, although 
in both molars the lingual border of the talonid forms a cingular shelf (Fig. S1 A), as in m1. There is a welldeveloped postcingulid at least on $\mathrm{m} 3$.

In sum, MJHG-NCP 58 is closer to the holotype of $P$. schlosseri by sharing similar size, high mandibular ramus with convex ventral border, diastemata absent, bulbous roots, p1-p2 with small distal heel bearing small cuspid, $\mathrm{m} 1$ with tall talonid cuspid, and lingual border of the talonid reaching the lingual base of the protoconid. Oblique p1, previously interpreted as a diagnostic character of $P h$. lacerans (Marshall, 1978), might be also present in the holotype of $P$. schlosseri and would not be a differential character. MJHG-NCP 58 differs from the holotype (MLP 11-114) in having more bulbous roots, molars with somewhat broader anterobasal cingulid, and smaller talonids. These differences, which are essentially in proportions, could be due to intraspecific variation although this cannot be evaluated as since to date this taxon was known only through the holotype and the very fragmentary MLP 11-115, both from the presumably Mustersan Roth's "Cretáceo Superior del Lago Musters". Cladera et al. (2004) reported an additional specimen from the Gran Hondonada locality, but it is still undescribed.

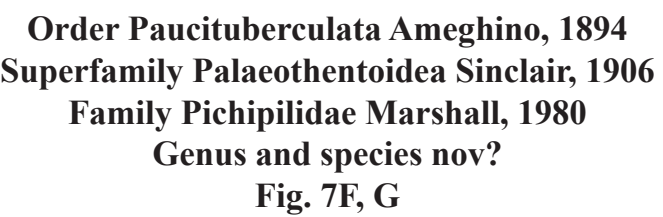

Referred specimens and provenance. MJHG-NCP 277, fragment of left dentary with $\mathrm{m} 2$ ? (CY3); MJHG-NCP 278, left mandibular fragment with four alveoli, p3?, and alveolus for root of m1? (CY3).

Description. The only tooth preserved in MJHG-NCP 277 (Fig. 7F) sets in a fragmentary dentary, which also preserved the alveoli for a preceding and a subsequent tooth. The alveoli have similar dimensions to the roots of the tooth preserved. This feature, in addition to the deep hypoconulid notch on the distal aspect of the molar preserved, suggest that the tooth was in the middle of the molar series $(\mathrm{m} 2$ or $\mathrm{m} 3)$. Considering that the $\mathrm{m} 4$ is reduced in most paucituberculatans, we interpret the tooth preserved is more likely an $\mathrm{m} 2$.

The crown is roughly rectangular (longer than wide) (Fig. 7F). The trigonid has a large protoconid (the largest cuspid of the trigonid), mesially displaced metaconid (relative to the protoconid), and reduced paraconid (smaller than the metaconid). The paraconid and metaconid are close and their bases are coalescent. The preprotocristid and postprotocristid are almost transverse. The anterobasal cingulid is very salient but transversally short, extending on the mesial bases of the paraconid and protoconid. The hypoconulid notch is conspicuous and sets at the base of the paraconid suggesting the contact with a preceding tooth with salient hypoconulid. There are short crests descending from the distal aspect of the protoconid and metaconid towards the talonid (protoconid and metaconid posterior crests, respectively; following Abello, 2013). The talonid is longer and wider than the trigonid, and cuspids are nearly as high as those of the trigonid. The hypoconid is large and salient (considering the labial margin of the protoconid). The cristid obliqua orients to the protoconid distal crest but separates from it by a well-defined notch. The postcristid curves lingually and ends within the talonid basin. The entoconid is the dominant cusp of the talonid, taller than the hypoconid, and laterally compressed. It is located roughly in line with the hypoconid, although its distal margin is slightly more mesial than the distal margin of the hypoconid. The flat face of the entoconid orients mesiolabially (instead of mesiodistally). There is a shallow groove on the flat labial face of the entoconid. The entocristid is curved in occlusal view and directs to (but does not contact) the metaconid distal crest. The postentocristid curves labially and ends within the talonid basin. The hypconulid is large and placed distal to the entoconid; it is salient, somewhat transversally lophoid, and isolated from the remaining cuspids.

The molar MJHG-NCP 277 shows two features that were considered synapomorphies of Paucituberculata (i.e., developed and salient hypoconid on $\mathrm{m} 2-\mathrm{m} 3$ and laterally compressed entoconid on $\mathrm{m} 1-\mathrm{m} 3$, see Goin et al., 2009; Abello, 2013), in addition to the reduction of the paraconid seen in most paucituberculatans 
(Abello, 2007). Among them, MJHG-NCP 277 is referable to Palaeothentoidea by the presence of metaconid and protoconid posterior crests (Goin et al., 2009; Abello, 2013), and in particular to Pichipilidae by possessing a wide talonid basin, metaconid mesially placed, concave entocristid, and postentocristid labially curved and ending in the talonid basin (see Abello, 2013; Goin et al., 2010).

The specimen MJHG-NCP 278 (Fig. 7G) is a left fragment of dentary with the crown of a premolar, the roots of the two preceding teeth, and a large alveolus for the mesial root of the subsequent tooth. Because its relative large size, we interpret that the later could belong to the $\mathrm{m} 1$, and therefore the preserved crown is likely a p3. The premolar has a main cusp lingually bent (characteristic of Pichipilidae; Abello, 2013). There is a talonid developed mainly on the distolingual side of the crown. The premolar lacks lingual crests, as seen in Pilchenia and its kin (the Pilchenia group, Abello, 2013).

Comparisons. Pichipilidae are typical South American early (Colhuehuapian and Santacrucian) to middle (Friasian) Miocene marsupials represented by the genera Pichipilus and Phonocdromus (Abello, 2013). The oldest pichipilid is the middle Eocene (Casamayoran age) Quirogalestes almagaucha, with the most primitive molar morphology for the group (Goin and Candela, 1998), depicted by having the protoconid less reduced, according to the base preserved (Goin and Candela 1998) (this cusp is more robust in MJHG-NCP 277), paraconid and metaconid slightly separated (the bases of these cusps are coalescent in MJHG-NCP 277), metaconid aligned with protoconid (mesially displaced in MJHG-NCP 277) (see description of Q. almagaucha in Goin and Candela, 1998). The condition of MJHG-NCP 277 for those features is derived in the context of pichipilids. In turn, $Q$. almagaucha and MJHG-NCP 277 retain the primitive condition of having a short anterobasal cingulid that extends over the mesial bases of metaconid and protoconid. The anterobasal cingulid in MJHG-NCP 277 is however, very salient. Moreover, MJHG-NCP 277 is nearly 30\% larger than the m2 of Quirogalestes almagaucha.

Early Pichipilidae were also mentioned for the early Oligocene Patagonian assemblages La Cantera and likely also La Cancha (Goin et al., 2010). An indeterminate specimen from La Cantera (MPEF-PV 3828) differs from MJHG-NCP 277 by having metaconid and paraconid similar in height (paraconid lower than metaconid in MJHG-NCP 277) and long anterobasal cingulum that extends to the base of the hypoconid (Goin et al., 2010) (transversally short in MJHG-NCP 277). However, there is another specimen from La Cantera (MPEF-PV 3910) that is similar to MJHG-NCP 277 in these features (following Goin et al., 2010). Both specimens from La Cantera are considerably smaller than MJHG-NCP 277 (Goin et al., 2010). In other features (lower molars with wide talonids, entoconid laterally compressed, short entocristid oriented towards the talonid basin, well-developed postentocristid; metaconid mesially placed respect to the protoconid, protoconid and metaconid with posterior crests), MJHG-NCP 277 is similar to specimens from La Cantera. In turn, the specimens tentatively assigned to Pichipilidae from La Cancha lack the protoconid and metaconid posterior crests (Goin et al., 2010), in this regards deferring from MJHG-NCP 277 and others pichipilids (see Abello, 2013 for diagnosis of the group). Specimen MPEF-PV 4494 from La Cancha is larger than specimens from La Cantera (Goin et al., 2010), but still smaller than MJHG-NCP 277.

The Deseadan Pseudhalmarhiphus guaraniticus is a species named by Ameghino (1899) based on a right dentary with m1-m2. The specimen is lost from the collection (see Patterson and Marshall, 1978; Abello, 2007; Marshall, 1980) and the only available information to date is the description and the illustration of the $\mathrm{m} 2$ provided by Ameghino $(1899,1902 \mathrm{a}, 1903)$. The specimen was considered a Caenolestidae (=Caenolestinae in Reig, 1955; Patterson and Marshall, 1978; Marshall, 1980) but this assignation was questioned by Abello (2007) based on the poor available evidence to verify diagnostic features. However, more recently Reguero and Goin (2021) mentioned this taxon in a faunal list as a Pichipilidae. Considering the available information, P. guaraniticus is smaller than MJHG-NCP 277 and differs from it by its more gracile morphology, proportionally longer and narrower tooth, paraconid and metaconid separated by a deep valley, trigonid with sharp and high cuspids (Patterson and Marshall, 1978), entoconid lacking an obvious flat surface as seen in MJHG-NCP 277 (according to the drawing in Ameghino's contributions). The anterobasal cingulid is short (Patterson and Marshall, 1978), as in MJHG-NCP 277. We agree with Abello's (2007) taxonomic consideration in the absence of the specimen to verify its morphology. Even considering the hypothesis that P. guaraniticus is a pichipilid, MJHG-NCP 277 is not referable to this species. 
Comparing MJHG-NCP 277 with the Neogene pichipilids, Pichipilus has derived condition of possessing the paraconid and metaconid sub-equal in size (in MJHG-NCP 277 which we interpreted it conserves probably the $\mathrm{m} 2$, the metaconid is larger), paraconid and metaconid coalescent; consequently, it appears a single lingual cusp when molars are worn (only the bases of the paraconid and metaconid are coalescent in MJHG-NCP 277), oblique postparacristid mesiolabially-distolingually oriented (transverse in MJHG-NCP 277), long anterobasal cingulid (short in MJHG-NCP 277), trigonid cuspids as tall as those of the talonid (trigonid cuspids slightly taller than those of the talonid in MJHG-NCP 277). Most species of the genus (Pichipilus riggsi, P. centinelus, and P? halleuxi if the assignation to the genus were correct-see Abello, 2007 for discussion) are smaller to MJHG-NCP 277, while P. osborni is in its range (e.g., Marshall and Pascual, 1977 for measurements). Phonocdromus has also a long anterobasal cingulid, hypoconid as tall as the protoconid (lower in MJHG-NCP 277), and much smaller size (see Reig, 1955; Marshall and Pascual, 1977; Marshall, 1980; Abello, 2007 for descriptions).

In sum, the differences noted above among MJHG-NCP 277 and other pichipilids suggest that the material from the Las Chacras Formation could represent a new taxon. The size MJHG-NCP 278 is compatible with MJHG-NCP 277, and both might belong to the same taxonomic entity.

\section{Subclass Eutheria Gill, 1872 \\ Order Cingulata Illiger, 1811 \\ Family Dasypodidae Gray, 1821 \\ Genus Isutaetus Ameghino, 1902b}

Type species. Isutaetus depictus Ameghino, 1902b

Distribution. Mustersan SALMA (late middle Eocene); Chubut and Río Negro provinces, Argentina (Simpson, 1948; this work).

\section{Isutaetus depictus Ameghino, 1902b}

Fig. 7C

Referred material and provenance. MJHG-NCP 21, two isolated movable osteoderms (CY1); MJHG-NCP 22, one fixed isolated osteoderm (CY1); MJHG-NCP 24, six probably associated osteoderms (five fixed and one movable) (CY3); MJHG-NCP 26, three fixed probably associated osteoderms (CY3); MJHG-NCP 261, one isolated osteoderm (CH2); MJHG-NCP 274, four probably associated isolated osteoderms (three fixed and one fragment movable), and a fragment of one movable osteoderm (CY3).

Remarks. Simpson (1948) considered the type species Isutaetus depictus as co-generic with the type species Pseudeutatus clypeus and proposed the new combination Pseudeutatus depictus. According to Simpson (1948:75), the taxa included in Pseudeutatus have five or more small foramina confined to the posterior edge of the osteoderms. However, the lectotype of Isutaetus depictus (MACN A 10961), selected by Simpson (1948:92, plate 8, fig 3) (see also Ciancio and Carlini, 2008: 231, fig 4A), has 12 foramina on the posterior margin of the osteoderm, in addition to one and two small foramina on each lateral margin. Moreover, the lectotype of Isutaetus depictus differs markedly from the type specimen of Pseudeutatus clypeus by having wide and deep grooves on the external surface of the osteoderm delimiting prominent main and peripheral figures, while in Pseudeutatus clypeus these features are practically imperceptible. Consequently, we recognize Isutaetus depictus as belonging to a genus separate from that typified by Pseudeutatus clypeus. Ameghino (1902b) described a second species of Isutaetus, I. petrinus, presumably from Deseadan beds. We agree with Ciancio and Carlini (2008) that this species more properly belongs to a different genus.

Osteoderms from lower Las Chacras Formation share the following characters supporting their assignation to Isutaetus depictus: smooth external surface with evident sulci separating anterior and lateral peripheral figures from the principal one, two to six small foramina within the sulci, caudal border with one or two rows of 12 to 16 small foramina and three to six small foramina on each lateral margin (Fig. 7C). The fixed 
osteoderms vary from 6.40-7.00 $\mathrm{mm}$ width and from 9.10-11.50 $\mathrm{mm}$ long. No complete movile osteoderm is available in our sample. The type of Isutaetus depictus derives from an undetermined Mustersan locality bearing Ameghino's (1902b) Couches á Astraponotus. The only previously referred specimen derives from Roth’s "Cretáceo Superior Lago Musters" (Simpson, 1948).

\section{Order Astrapotheria Lydekker, 1894 \\ Family Trigonostylopidae Ameghino, 1901 \\ Genus Trigonostylops Ameghino, 1897}

Type species. Trigonostylops wortmani Ameghino, 1897

Distribution. Riochican to Mustersan SALMAs (early to late middle Eocene); Chubut and Río Negro provinces, Argentina (Simpson, 1967; Pascual et al., 1984).

\section{Trigonostylops sp.}

Referred material and provenance: MJHG 101Pa, isolated upper molar (?CY1).

Remarks. Even though the specimen could not be found in the MJHG collection, a drawing was provided by Carbajal et al. (1977: fig. 1d). At least the general features displayed in the drawing agree with those known for the M1 or M2 of Trigonostylops wortmani (e.g., MACN A 10642, AMNH 28700), but specific identification is unfeasible since the upper dentition of T. gegenbauri (Roth, 1899) is unknown.

\section{Family Astrapotheriidae Ameghino, 1887 Genus Astraponotus Ameghino, 1901}

Type species. Astraponotus assymmetrus Ameghino, 1901

Distribution. Mustersan SALMA (late Eocene); Chubut and Río Negro provinces, Argentina (Simpson, 1967; Kramarz et al., 2010; Pascual et al., 1984).

\section{Astraponotus sp.}

Fig. 6A, B, C

Referred specimens and provenance. MJHG 146Pa, right maxillary fragment with erupting P2 and alveolus for $\mathrm{C} 1$, partial symphysis with erupting incisor (i2?), roots of two incisors and partial alveoli for two incisors and canines, left mandibular fragment with erupting p3-p4, erupted m1-m2 and encrypted $\mathrm{m} 3$, and right mandibular fragment with erupting $\mathrm{p} 4$ and erupted $\mathrm{m} 1-\mathrm{m} 2$ (CY1); MJHG 176Pa, probably associated i3 and partial upper molar (CY1); MACN Pv 17587, isolated left P3 (CY1); MJHG-NCP 251, partial skull with complete right C1-M3 series (CH1); MJHG-NCP 254; probably associated upper canine, upper molar, partial upper premolar, lower incisor, and fragment of lower canine (CH1).

Remarks. All these remains agree with Astraponotus and differ from Albertogaudrya by the size (molars of Astraponotus are 25-30\% larger), crown height (lower crowned in Albertogaudrya), upper molars with well-developed metaloph (rudimentary in Albertogaudrya), lower molars with longer paralophid and lophoid entoconid (bunoid in Albertogaudrya). The preserved characters of the skull MJHG-NCP 251 (Fig. 6C) agree with those of Astraponotus skull described by Kramarz et al. (2010), although with slightly more slender proportions (skull of Albertogaudrya is unknown). No remain in the Casamiquela collection is referable to Albertogaudrya. Astraponotus and its synonyms were defined upon very fragmentary materials described by Ameghino (1901) and Roth (1903) from central Patagonia. Kramarz et al. (2010) described additional and much more complete materials from presumably equivalent levels at the Gran Hondonada locality and at the eastern slope of Cerro Talquino in central Patagonia. This is the northernmost known record of Astraponotus and the first outside central Patagonia. 


\section{cf. Astraponotus sp. \\ Fig. 6D, E}

Referred specimen and provenance. MJHG-NCP 269, probably associated upper and lower premolar (CH2). Remarks. The upper premolar (Fig. 6D) resembles the P3 of the partial skull MJHG-NCP 251 listed above, but it is slightly smaller (17.9 mm length, $24.6 \mathrm{~mm}$ width), more quadrangular, it lacks a labial fold of the metacone, and the basal cingulum has no distolingual broadening (in hypocone position). Moreover, it lacks a distal connection between protocone and ectoloph (i.e., postprotocrista or equivalent), and thus the central valley opens distolingually, although the condition in MJHG-NCP 251 is obscured by being more worn. The pattern in MJHG-NCP 269 is similar to that observed in the P4 of Oligocene and Miocene, more advanced astrapotheriids (see for example Gaudry, 1904: fig. 19; Kramarz and Bond, 2010: fig. 12.4B). Nevertheless, premolars of post-Eocene astrapotheriids are definitively higher crowned and two-rooted (the lingual and the distolabial roots are typically fused). Additionally, the labial fold of the metaloph on premolars, usually conspicuous in Eocene astrapotheriids, is lacking in the partial premolar included within the syntype of Astraponotus assymmetrus (MACN A 10971).

The lower premolar (Fig. 6E) is a small (11.7 mm length, $8.9 \mathrm{~mm}$ width), single rooted tooth with a single cusp slightly keeled mesiodistally and a small distal, talonid-like heel. It is similar to the $\mathrm{p} 2$ of Astraponotus specimens from Chubut (see Kramarz et al., 2010) but rather smaller, the central cusp is more conical, and the distal heel is higher. Nevertheless, this tooth also resembles the p3 of the late Oligocene Parastrapotherium holmbergi (see Kramarz and Bond, 2008, fig: 5.1-3), although the Deseadan species is much larger, the distal heel has a more distinct talonid basin and cuspid, and it has a small mesial paraconid-like cuspid.

In sum, we conclude that these doubtfully associated teeth do not belong to any known Oligocene or younger astrapothere, but more likely to a taxon close to Astraponotus but with somewhat more apomorphic dental characters.

\section{Order Pyrotheria Ameghino, 1895 \\ Family Pyrotheriidae Ameghino, 1895 \\ Genus Propyrotherium Ameghino, 1901}

Type Species. Propyrotherium saxeum Ameghino, 1901

Distribution. Mustersan SALMA (late middle Eocene); Chubut, Catamarca, and Río Negro provinces, Argentina (Simpson, 1967; Kramarz and Bond, 2014; Babot et al., 2017; this work). Specimens associated with the notohippid Eomorphippus (see Kramarz and Bond, 2014) suggest that Propyrotherium also occurs in rocks referable to the Tingurirican SALMA (early Oligocene).

\section{Propyrotherium saxeum Ameghino, 1901}

Fig. 6F-H

Referred specimens and provenance. MJHG 254Pa, isolated tusk (CY1); MJHG-NCP 3, isolated m2? (CH1); MJHG-NCP 267, partial tusk and fragments (CH1); MJHG-NCP 268, isolated m1?; MJHG-NCP 272 , tooth fragment $(\mathrm{CH} 1)$.

Remarks. The tusk MJHG 254Pa (Fig. 6F) is a rootless, very long $(191 \mathrm{~mm})$, gently curved, and roughly sub-cylindrical tooth, more convex on the lingual and labial faces. The mesio-distal width is $23.2 \mathrm{~mm}$, the labio-lingual is $30.1 \mathrm{~mm}$. The enamel is limited to the apical quarter of the crown height and to the labial, and distolabial faces. The dentine bears longitudinal striations, more marked on the lingual surface. Judging by the slight curvature, this tusk compares better with the lower than with the upper tusks of Pyrotherium. The cheek teeth MJHG-NCP 3 (Fig. 6G) and MJHG-NCP 268 (Fig. 6H) are massive, longer than wide, bunolophodont teeth, with two transverse crests and a distal cuspate shelf. Both compare well with the isolated $\mathrm{m} 1$ or $\mathrm{m} 2$ of $P$. saxeum described by Kramarz and Bond (2014). MJHG-NCP 3 is somewhat larger and proportionally broader and could correspond to an $\mathrm{m} 2$ whereas MJHG-NCP 268 could be an $\mathrm{m} 1$. 


\section{Order Pyrotheria? \\ Fig. S1 B, C}

Referred specimens and provenance. MJHG-NCP 13, an isolated premolar (CY2); MJHG-NCP 14, an isolated tusk fragment (CY2).

Remarks. The teeth were found physically unassociated, but very close to each other and might correspond to the same individual. The premolar MJHG-NCP 13 (Fig. S1 C) (length=15.3 mm, width=8.7 mm) has a massive, centered, somewhat backwards recurved and conical cuspid, with a very low accessory cuspule on the mesial aspect of the main cuspid, and a small cuspule on the distal base, forming a minute heel. The cuspules are connected by a feeble labial? cingulid demarcated by an irregular succession of minute enamel denticles, resembling the basal crenulations observed in some cheek teeth of Propyrotherium and Pyrotherium (see Kramarz and Bond, 2014). There is a minute wear facet at the apex of the main cuspid, and no facets for contiguous teeth are observed. The tooth bears a single, very robust, and labiolingually compressed root. This tooth might belong to an anterior lower premolar (p2?) of a pyrothere, although its attribution to an astrapothere with anterior premolars less lophodont (lower crowned) than in Albertogaudrya and Astraponotus cannot be discarded.

MJHG-NCP 14 (Fig. S1 B) is an apical portion of a small, unworn tusk. The labio-lingual width at the preserved base is $15.3 \mathrm{~mm}$ and the mesio-distal length is $16.5 \mathrm{~mm}$. The crown is slightly recurved, being likely the lingual (anterior) side the more concave wall. The basal cross section is D-shaped, being the flat surface likely the mesial wall. The enamel is lacking on the entire labial wall and the labial portion of the mesial wall. On the contrary, upper and lower tusks of Propyrotherium and Pyrotherium have typically enameled labial wall.

\section{Order Litopterna Ameghino, 1889 \\ Genus and species indet. \\ Fig. 7A}

Referred specimen and provenance. MJHG-NCP 256, isolated upper tooth (CH2).

Remarks. This is a very low crowned, roughly quadrangular tooth (length $=11.9 \mathrm{~mm}$, width $=12.6 \mathrm{~mm}$ ), with a very marked labial flexus (ectoflexus) (Fig. 7A). The cusps are bunoid and the cristae are patent but low and do not form real lophs. The parastyle is conspicuous, mesiolabial to the paracone and connected through a sharp, litoptern-like preparacrista. The mesostyle is represented by a low but massive cusp attached to the mesiolabial base of the metacone. The postparacrista is very low, with a feeble contact with the metastyle, and thus there is no real labial wall. The protocone has well distinct pre- and postprotocrista connecting paraconule and metaconule respectively and enclosing the trigon basin. The preparaconular crista is strong and reaches the preparacingulum, the postparaconular crista is lacking. Both pre-and postmetaconular cristae are short but conspicuous. The protostyle is low and broad, and defines a well marked mesiolingual pocket. The hypocone is conspicuous and well separated from the metaconule. Although this tooth displays some "condylarth" appearance, it is more likely a deciduous tooth of an undetermined litoptern (Proterotheriidae?).

\section{Family Adianthidae Ameghino, 1891 Adianthidae genus and species nov.} Fig. 7B

Referred specimen and provenance. MJHG-NCP 257, left mandibular fragment with p3-m1 (CH2). Descriptions and comparisons. The three preserved cheek teeth are bunolophodont, with the lophids arranged in a typically bicrescentic pattern defining a main labial flexid separating protoconid from hypoconid, and two sub-equal lingual flexids invading the trigonid and the talonid respectively (Fig. 7B). The premolars are longer than wide, fully molariform, with complete talonid as large as the trigonid, even wider on $\mathrm{p} 4$. The $\mathrm{m} 1$ is somewhat wider than the premolars, with transversally longer paralophid, much larger entoconid, and 
more distinct hypoconulid. MJHG-NCP 257 differs from the middle Eocene Oxybunotherium (presumably synonym of Proectocion, Cifelli and Soria, 1983) in having more bunodont crowns, distolabially shorter trigonid, transversally shorter paralophid, and continuous mesiolingual cingulid. It differs from the late Oligocene Proadiantus excavatus by having lower crowned cheek teeth, less penetrating labial flexid, shelflike precingulid present on the entire mesial base of the crowns, proportionally broader and more molariform p3-p4. Differs from Tricoelodus bicuspidatus (late Oligocene) by being much smaller, by having p4 with complete talonid, lower precingulid, and lingually open talonid basin, $\mathrm{m} 1$ with wider trigonid and talonid basins (base of cuspids does not invade the basins), hypoconulid not extended distally and thus without hypoconulid-entoconid basin and hypoconid-hypoconulid sulcus. Differs from Tricoelodus boliviensis in having hypoconulid not extended distally and thus without hypoconulid-entoconid basin on m1. Similarly, it differs from Thadanius hoffstetteri (premolars unknown) in being smaller, cuspids and lophids are more delicate and thus with wider trigonid and talonid basins. The Adianthidae indet. recorded for the Mustersan Gran Hondonada is based on an isolated m3 (Cladera et al., 2004), and thus not comparable with MJHG-NCP 257.

In sum, comparisons with known Paleogene adianthids indicate that MJHG-NCP 257 belong to a distinct taxon, which will be described formally in a further article currently in progress.

\section{Order Notoungulata Roth, 1903 \\ "Isotemnidae" Ameghino, 1897 \\ Genus Periphragnis Roth, 1899}

Type species. Periphragnis harmeri Roth, 1899

Distribution. Mustersan and Tinguirirican SALMAs (late middle Eocene-early Oligocene). Patagonia and central Chile (Simpson, 1967; Flynn et al., 2003; Bradham et al., 2015).

\section{Periphragnis palmeri (Roth, 1903) \\ Fig. 5H}

Referred materials and provenance. MJHG-NCP 11, partial left mandibular ramus with p2-m3 (CY1); MJHG-NCP 12, left maxillary fragment with M2-M3 and fragments of bones and teeth (CY1).

Remarks. The M2-M3 of MJHG-NCP 12 compare well with the isotemnid described by Roth (1903) as Calodontotherium palmeri [later transferred by Simpson (1967) to the genus Periphragnis], both in size, morphology, and especially in the complete absence of lingual cingula. They differ from the Eocene isotemnids Rhyphodon lankesteri and Distylophorus alouattinus by being somewhat larger and from Periphragnis harmeri by having less prominent paracone fold on the ectoloph and by lacking lingual cingula. The Tinguirirican isotemnid Periphragnis vicentei described by Bradham et al. (2015) is larger than MJHG-NCP 12 and the molars have weak cingula. No lower cheek tooth has been previously referred to Periphragnis palmeri. Nonetheless, the partial mandible MJHG-NCP 11 (Fig. 5H) is provisionally referred to this species since the size of the lower cheek teeth are consistent with the uppers of MJHG-NCP 12 and concordantly lack lingual cingulids.

The type specimen and only previously known specimen is derived from Roth's (1903) "Cretáceo Superior del Lago Musters".

\section{?Periphragnis circunflexus (Ameghino, 1901)}

Fig. 5G

Referred material and provenance. MJHG-NCP 252, four associated lower cheek teeth, probably p3, p4, $\mathrm{m} 1$ and partial $\mathrm{m} 2$, one incisor-like lower tooth, a partial upper molar, and associated cranial and mandibular fragments $(\mathrm{CH} 2)$.

Remarks. The teeth MJHG-NCP 252 (Fig. 5G) belong to a large Isotemnidae, similar in size to those of the type of?Periphragnis circunflexus (MACN A 10896) (see Simpson, 1967), clearly larger than in P. harmeri, P. palmeri, and other isotemnids as P. exauctus, Rhyphodon lankesteri or Distylophorus alouattinus. 
The species Periphragnis vicentei, from the Tinguirirican of Chile (Bradham et al., 2015), is known only by upper molariforms, although they are proportionally smaller than the lower teeth of MJHG-NCP 252.

This species was originally described as Asmodeus circunflexus by Ameghino (1901) and later transferred tentatively to the genus Periphragnis by Simpson (1967). According to Ameghino (1901), the type (MACN A 10896) comes from Astraponotus beds at Colhué-Huapi.

\section{Periphragnis sp. \\ Fig. 5I}

Referred material and provenance. MJHG 148Pa, associated left $\mathrm{p} 3-\mathrm{m} 1$, right $\mathrm{p} 3$, partial lower molar and partial upper molar (CY1).

Remarks. The specimen MJHG 148Pa was originally catalogued as Leontiniidae in the MJHG collection. However, the premolars have a short talonid and the area of the entoconid is reduced (Fig. 5I). On the contrary, premolars of leontiniids have longer talonid and large entoconid. The molars of MJHG 148Pa are much worn and no significant occlusal features are discernible. However, even the less worn teeth lack any trace of the deep lingual flexid between the trigonid and talonid, which is typically present in leontiniids, even in worn specimens. MJHG 148Pa more likely belongs to an isotemnid; the morphology of the premolars matches with that of the species of Periphragnis. It differs from the lower molars here referred to P. palmeri (MJHG-NCP 252) in having conspicuous lingual cingulids, and from ?Periphragnis circunflexus by being significantly smaller. Therefore, MJHG 148Pa very likely belongs to a third species of Periphragnis, although the teeth are too worn for a more accurate identification.

\section{"Notohippidae" Ameghino, 1895 \\ Genus Puelia Roth, 1902}

Type species. Puelia plicata Roth, 1902

Distribution. Mustersan SALMA (late middle Eocene) and Tinguirirican SALMA; Chubut and Río Negro provinces (Simpson, 1967; López et al., 2010; this work).

\section{Puelia sigma (Ameghino, 1901)}

Fig. 5E, $F$

Referred materials and provenance. MJHG-NCP 2, associated left maxillary fragment with roots of P4, complete $\mathrm{P} 3$, M1-M3, right maxillary fragment with P1-P3, and three upper anterior teeth (I1, I2, and I3 or C1) (CH2); MJHG-NCP 5, right mandibular fragment with m2-m3 (CH2); MJHG-NCP 25, right mandibular fragment with partial m1-m3 (CY3); MJHG-NCP 27, right mandibular fragment with p3-p4 and associated incisor and fragments (CY3); MACN Pv 17588, left mandibular fragment with m1-m2 (CY1); MACN Pv 17589, right mandibular fragment with $\mathrm{p} 3-\mathrm{m} 3$ (CY1).

Remarks. Puelia is a basal toxodontian traditionally classified within Notohippidae (see López et al., 2010 and reference therein), currently interpreted as a non-monophyletic family (e.g., Shockey, 1997; Cerdeño and Vera, 2010; Martínez et al., 2020). The specimens here referred to Puelia sigma are lower crowned than in Eomorphippus (Tinguirirican) and younger notohippids. The upper molars (Fig. 5E) differ from those of Pampahippus (Casamayoran) in having more cuspules stemming from the lingual aspect of the ectoloph, but less than in Plexotemnus (Casamayoran). The postcingulum is more elevated than in Pampahippus and Plexotemnus. The lower molars (Fig. 5F) have more lophoid entolophid than in Pampahippus and Plexotemnus, and the metaconid bears a distal projection that reaches the entoconid (absent in Pampahippus and Plexotemnus). The size of the cheek teeth match with those of Puelia sigma and are smaller than in Puelia coarctatus.

Puelia sigma has been recorded in the Mustersan localities Cerro del Humo and Gran Hondonada (Simpson, 1967; Cladera et al., 2004), and from the Tingurirican Vera Member of the Sarmiento Formation at Gran Barranca South of Colhué-Huapi Lake, central Patagonia (López et al., 2010). 
Nomenclatorial remarks. Puelia sigma (Ameghino, 1901) is based on lower cheek teeth, whereas Puelia plicata Roth, 1902 is based on uppers of equivalent size, both smaller than in Puelia coarctatus (Ameghino, 1901). Specimens with upper cheek teeth referable to Puelia plicata co-occur with specimens preserving lower cheek teeth referable to Puelia sigma in the same localities and same levels of the Las Chacras Formation, as well in the Sarmiento Formation at the Gran Hondonada in central Patagonia (Cladera et al., 2004). Therefore, they are very likely the upper and lower dentition of the same taxon. López et al. (2010) already suggested this synonymy being $P$. plicata the senior synonym. However, $P$. sigma has priority over P. plicata and thus it is the valid name for this species.

\section{Family Interatheriidae Ameghino, 1887 Interatheriidae indet.}

Fig. 5D

Referred materials and provenance. MJHG-NCP 28, right maxillary fragment with C1-P1 and roots for P2 (CY3); MJHG-NCP 276, isolated right c1? (CY3).

Remarks. These specimens belong more likely to one or more species of "Notopithecinae", than to "Interatheriinae".

\section{"Family Archaeohyracidae" Ameghino, 1897 Genus Pseudhyrax Ameghino, 1901}

Type species. Pseudhyrax eutrachytheroides Ameghino, 1901

Distribution. Mustersan and Tinguirirican SALMAs (late middle Eocene-early Oligocene); Patagonia, Northwestern Argentina, and central Chile. (Simpson, 1967; Flynn et al., 2003; García-López et al., 2020).

\section{Pseudhyrax eutrachytheroides Ameghino, 1901 Figs. 5A, B; S1 D}

Referred materials and provenance. MJHG-NCP 4, two isolated upper premolars (CH2); MJHG-NCP 7 , isolated right $\mathrm{m} 3$ (CH2); MJHG-NCP 8, left maxillary fragment with P4-M1 (CH2); MJHG-NCP 9, left mandibular fragment with $\mathrm{p} 2$ (CH2); MJHG-NCP 15, right maxillary fragment with M1? (CY1); MJHG-NCP 23, isolated partial lower molar (CY3?); MJHG-NCP 255, probably associated left $\mathrm{p} 3$ or $\mathrm{p} 4$, and $\mathrm{m} 1-\mathrm{m} 3$ (CH2); MJHG-NCP 258, right mandibular fragment with very worn p2-p4 (CH2); MJHG-NCP 259, probably associated right $\mathrm{p} 2-\mathrm{p} 4, \mathrm{~m} 3$, and left $\mathrm{p} 1$ ? (CH2); MJHG-NCP 260, right maxillary fragment with M1 or M2 (CH2); MJHG-NCP 263, left premaxillary fragment with two incisors, left maxillary fragment with P1, two isolated upper molars, and one lower molar, and fragments (not associated) (CH2); MJHG-NCP 271, right mandibular fragment with $\mathrm{m} 1$ and partial $\mathrm{m} 2$ (CY3); MACN Pv 17217, associated right and left mandibular fragments with p2-m2 (CY1).

Remarks. These specimens match with the holotype of Pseudhyrax eutrachytheroides (MACN A 11662) and specimens referred by Simpson (1967) in size, general morphology and crown height. The upper molars (Fig. 5B) have very well developed paracone and parastyle, the metacone area is convex but not as prominent as the paracone. Upper labial fossetes and lower lingual fossetids are persistent and become wider with moderate wear. The lower molars (Fig. 5A) bear a small fossetid in the talonid, between the entoconid and the hypoconulid, and an ephemeral fossetid in the trigonid. Differ from Eohyrax and Punahyrax in having higher crowned teeth and from Archaeohyrax and Archaeotypotherium by being smaller and lower crowned.

Pseudhyrax eutrachytheroides is a basal typotherian traditionally included in the paraphyletic Family Archaeohyracidae (García-López et al., 2020 and references therein). It is very frequent in the Mustersan localities of central Patagonia, the Mustersan levels of the Geste Formation, and in the Tinguirirican levels of central Chile (Bond and Deschamps, 2010; Croft et al., 2003; García-López et al., 2020). 


\section{Genus Eohegetotherium Ameghino, 1901}

Type species. Eohegetotherium priscum Ameghino, 1901

Distribution. Mustersan and Tinguirirican SALMA (late middle Eocene-early Oligocene); Patagonia and central Chile (Simpson, 1967; Reguero et al., 2003).

\section{Eohegetotherium priscum Ameghino, 1901 \\ Figs. 5C, S1 E}

Referred specimen and provenance. MJHG-NCP 264, an isolated right upper molar (CH2).

Remarks. This isolated upper molar (Fig. S1 E) differs from all specimens referred above to Pseudhyrax eutrachytheroides (Fig. S1 D) by being much smaller (5.7 mm long, $5.1 \mathrm{~mm}$ wide), higher crowned, and by having more ephemeral enamel lakes and larger mesial and distal bands of exposed dentine. This tooth matches with the lectotype of Eohegetotherium priscum (MACN A 10988, see Fig. S1 F), although it is more worn. Eohegetotherium priscum is an archaeohyracid typotherian with more advanced dental features than in the species of Pseudhyrax (Billet, 2011).

The type of Eohegetotherium priscum comes from the Gran Barranca South of Colhué-Huapi Lake, presumably from the Ameghino's "Astraponotéen le plus supérieur", currently identified as "La Cancha" levels of the Vera Member of the Sarmiento Formation, which bears Tinguirirican mammals (Bellosi, 2010;Dunn et al., 2013). This taxon also occurs in the Tinguirirican fauna of Central Chile, although described as Protarchaeohyrax gracilis (Reguero et al., 2003).

Nomeclatorial remarks. Reguero et al. (2003) coined the generic name Protarchaeohyrax and designed the species Archaeohyrax gracilis Roth, 1903 as the genotypic one. The authors acknowledged that Eohegetotherium priscum and Archaeohyrax gracilis are synonyms, and that the former clearly has priority. However, they refused to use the name Eohegetotherium priscum since the type and hypodigm are isolated teeth and offered scant basis for morphological comparison (see discussion in Reguero et al., 2003). We interpret that, although fragmentary, the type of Eohegetotherium priscum shows clear diagnostic features that made it different from the other "archaeohyracids", as the Eocene Eohyrax and Pseudhyrax and the late Oligocene Archaeohyrax patagonicus. Thus, we conclude that the specimens from the Chilean Tinguirirican fauna described as Protarchaeohyrax gracilis by Reguero et al. (2003) and MJHG-NCP 264 described herein belong to the same taxon, for which Eohegetotherium priscum is the valid name. 
A

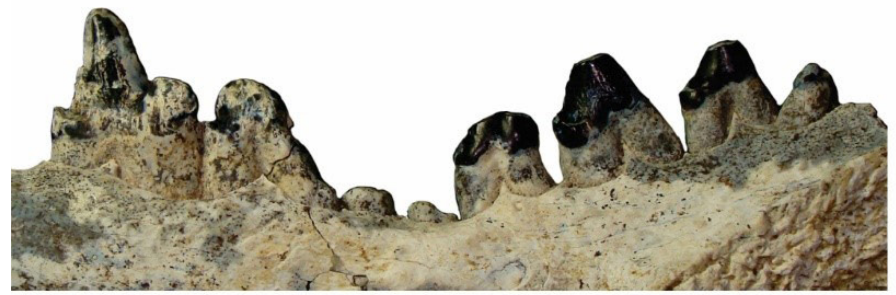

$10 \mathrm{~mm}$
D
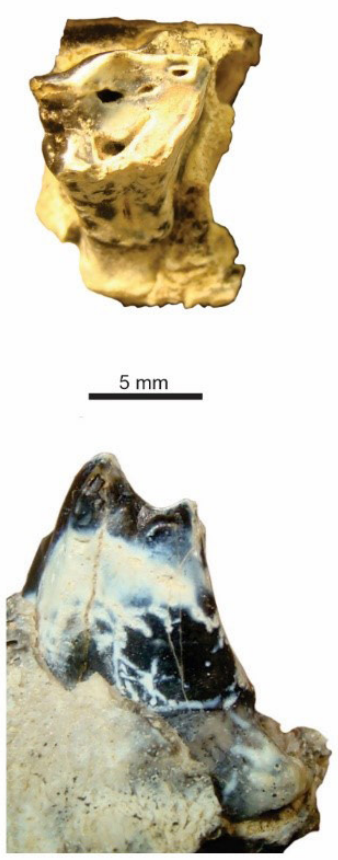

$E$
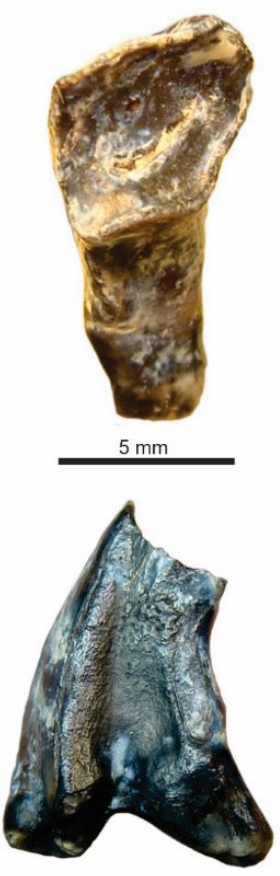

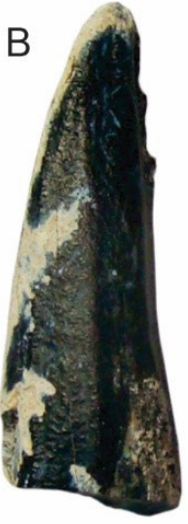

C

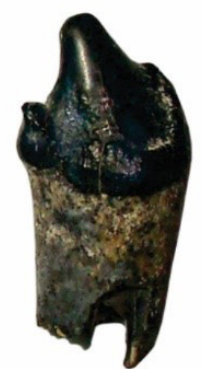

$10 \mathrm{~mm}$
$\mathrm{F}$
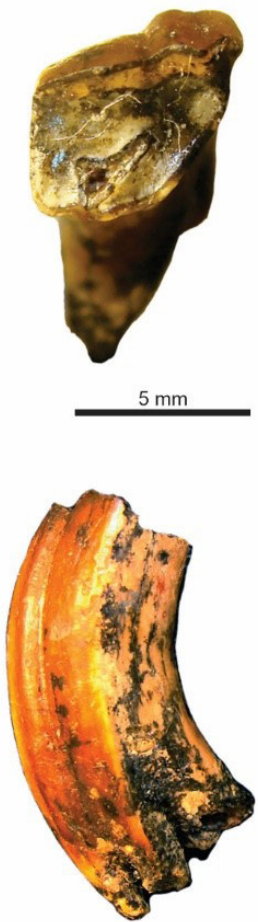

FIG. S1. A. Plesiofelis schlosseri, MJHG-NCP 58, left lower postcanine series (p1-p3, m1, roots of m2, and m3-m4) in lingual view. B. Pyrotheria or Astrapotheria, MJHG-NCP 14, isolated tusk fragment. C. MJHG-NCP 13, right lower premolar ion labial? view. D. Pseuhyrax eutrachytheroides, MJHG-NCP 15, right upper molar in occlusal (above) and mesial (below) views. E. Eohegetotherium priscum, MJHG-NCP 264, right upper molar in occlusal (above) and mesial (below) views. F. Lectotype of Eohegetotherium priscum, MACN A 10988, right upper molar in occlusal (above) and mesial (below) views. 


\section{References}

Abello, M.A. 2007. Sistemática y bioestratigrafía de los Paucituberculata (Mammalia, Marsupialia) del Cenozoico de América del Sur. Ph.D. Thesis (Unpublished), Universidad Nacional de La Plata: 381 p.

Abello, M.A. 2013. Analysis of dental homologies and phylogeny of Paucituberculata (Mammalia: Marsupialia). Biological Journal of the Linnean Society 109: 441-465.

Ameghino, F. 1887. Ennumeración sistemática de las especies de mamíferos fósiles coleccionados por Carlos Ameghino en los terrenos eocenos de Patagonia austral y depositados en el museo de La Plata. Museo de La Plata, Boletín 1: 1-26.

Ameghino, F.1889. Contribución al conocimiento de los mamíferos fósiles de la República Argentina. Academia Nacional de Ciencias en Córdoba, Actas 6: 1-1027.

Ameghino, F. 1891. Caracteres diagnósticos de cincuenta especies nuevas de mamíferos fósiles argentinos. Revista Argentina de Historia Natural 1: 129-167.

Ameghino, F. 1894. Enumération synoptique des espèces de mammifères fossiles des formations éocènes de Patagonie. Academia Nacional de Ciencias en Córdoba, Boletín 13: 259-455.

Ameghino, F. 1895. Prémière contribution a la connaissance de la faune mammalogique des couches a Pyrotherium. Instituto Geográfico Argentino, Boletín 15: 603-660.

Ameghino, F. 1897. Mammifères crétacés de 1'Argentine. Deuxième contribution a la connaissance de la faune mammalogique des couches a Pyrotherium. Instituto Geográfico Argentino, Boletín 18: 406-429, 431-521.

Ameghino, F. 1899. Sinopsis geológica-paleontológica. Suplemento (Adiciones y correcciones). Imprenta La Libertad: 13 p. La Plata.

Ameghino, F. 1901. Notices préliminaires sur des ongulés des terrains Crétacés de Patagonie. Academia de Ciencias en Córdoba, Boletín 16: 349-426.

Ameghino, F. 1902a. Sur le type primitif des molaires plexodontes des mammifères. Anales del Museo Nacional de Buenos Aires 3 (1): 419-439.

Ameghino, F. 1902b. Notices préliminaires sur des mammifères nouveaux des terrains crètacés de Patagonie. Academia de Ciencias en Córdoba, Boletín 17: 5-70.

Ameghino, F. 1903. Los diprotodontes del orden de los plagiaulacoideos y el origen de los roedores y de los polimastodontes. Anales del Museo Nacional de Buenos Aires 3 (1): 81-192.

Babot, M.J.; García-López, D.; Deraco, V.; Herrera, C.M.; Del Papa, C. 2017. Mamíferos Paleógenos del subtrópico de Argentina: síntesis de estudios estratigráficos, cronológicos y taxonómicos. In Congreso Geológico Argentino. No. 20, Relatorio, Ciencias de la Tierra y Recursos Naturales del NOA: 730-753. San Miguel de Tucumán.

Babot, M.J.; Powell, J.E.; Muizon, C de. 2002. Callistoe vincei, a new Proborhyaenidae (Borhyaenoidea, Metatheria, Mammalia) from the early Eocene of Argentina. Geobios 35: 615-629.

Bellosi, E. 2010. Physical stratigraphy of the Sarmiento Formation (middle Eocene-lower Miocene) at Gran Barranca, central Patagonia. In The Paleontology of Gran Barranca: Evolution and Environmental Change through the Middle Cenozoic of Patagonia (Madden, R.; Carlini, A.; Vucetich, M.; Kay, R.; editors). Cambridge University Press: 1931. Cambridge.

Billet, G. 2011. Phylogeny of the Notoungulata (Mammalia) based on cranial and dental characters. Journal of Systematic Palaeontology 9: 481-497.

Bond, M.; Deschamps, C.M. 2010. The Mustersan Age at Gran Barranca, a review. In The Paleontology of Gran Barranca: Evolution and Environmental Change through the Middle Cenozoic of Patagonia (Madden, R.; Carlini, A.; Vucetich, M.; Kay, R; editors). Cambridge University Press: 255-263. Cambridge.

Bradham, J.; Flynn, J.J.; Croft, D.; Wyss, A. 2015. New Notoungulates (Notostylopidae and Basal Toxodontians) from the Early Oligocene Tinguiririca Fauna of the Andean Main Range, Central Chile. American Museum Novitates 3841: 1-24.

Cabrera, A. 1927. Datos para el conocimiento de los dasyuroideos fósiles argentinos. Revista del Museo de La Plata 30: 271-315.

Carbajal, E.; Pascual, R.; Pinedo, R.; Salfity, J.; Vucetich, M.G. 1977. Un Nuevo mamífero de la formación Lumbrera (Grupo Salta) de la comarca de Carahuasi (Salta, Argentina). Edad y correlaciones. Publicaciones del Museo Municipal de Ciencias Naturales de Mar del Plata "Galileo Scaglia” 2: 148-163. 
Cerdeño, E.; Vera, B. 2010. Mendozahippus fierensis, gen. et sp. nov., new Notohippidae (Notoungulata) from the late Oligocene of Mendoza (Argentina). Journal of Vertebrate Paleontology 30: 1805-1817. doi: 10.1080/02724634.2010.520781.

Ciancio, M.R.; Carlini, A.A. 2008. Identificación de ejemplares tipo de Dasypodidae (Mammalia, Xenarthra) del Paleógeno de Argentina. Revista del Museo Argentino de Ciencias Naturales 10: 221-237.

Cifelli, R.L.; Soria, M.F. 1983. Systematics of the Adianthidae (Litopterna, Mammalia). American Museum Novitates 2771: 1-25.

Cladera, G.; Ruigomez, E.; Ortiz Jaureguizar, E.; Bond, M.; López, G.M. 2004. Tafonomía de La Gran Hondonada (Formación Sarmiento, edad-mamífero Mustersense, Eoceno Medio) Chubut, Argentina. Ameghiniana 41: $315-330$.

Croft, D.; Bond, M.; Flynn, J.J.; Reguero, M.; Wyss, A. 2003. Large Archaeohyracids (Typotheria, Notoungulata) from Central Chile and Patagonia, Including a Revision of Archaeotypotherium. Fieldiana Geology, New Series 49: 1-38.

Dunn, R.; Madden, R.; Kohn, M.; Schmitz, M.; Strömberg, C.; Carlini, A.; Ré, G.; Crowley, J. 2013. A new high precision $\mathrm{U}-\mathrm{Pb}$ chronology for middle Eocene-early Miocene South American Land Mammal Ages of the Sarmiento Formation, Gran Barranca, Chubut Province, Argentina. Geological Society of America Bulletin 125: 539-555.

Engelman, R.K.; Flynn, J.J.; Gans, P.; Wyss, A.R.; Croft, D.A. 2018. Chlorocyon phantasma, a late Eocene borhyaenoid (Mammalia: Metatheria: Sparassodonta) from the Los Helados locality, Andean Main Range, Central Chile. American Museum Novitates 3918: 1-22.

Flynn, J.J.; Wyss, A.R.; Croft, D.A.; Charrier, R. 2003. The Tinguiririca Fauna, Chile: biochronology, paleoecology, biogeography, and a new earliest Oligocene South American Land Mammal “Age". Palaeogeography, Palaeoclimatology, Palaeoecology 195: 229-259.

Forasiepi, A.M.; Babot, M.J.; Zimicz, N. 2015. Australohyaena antiqua (Mammalia, Metatheria, Sparassodonta), a large predator from the Late Oligocene of Patagonia. Journal of Systematic Palaeontology 13: 503-525.

García-López, D.A.; Gelfo, N.F.; Scanferla, A.; Babot, J.; Ferro, A.; Saade, L.S. 2020. The pre-Oligocene diversity of hypsodont typotherians (Mammalia, Notoungulata) in Northwestern Argentina. Ameghiniana 57: 117-131.

Gaudry, A. 1904. Fossiles de Patagonie. Dentition de quelques mammifères. Mémoires de la Société Géologique de France, Paléontologie $12: 1-27$.

Gill, T. 1872. Arrangement of the families of mammals with analytical tables. Smithsonian Miscellaneous Collections 11: $1-98$.

Goin, F.J.; Abello, M.A.; Chornogubsky, L. 2010. Middle Tertiary marsupials from central Patagonia (early Oligocene of Gran Barranca): understanding South America's Grande Coupure. In The Paleontology of Gran Barranca: Evolution and Environmental Change through the Middle Cenozoic of Patagonia (Madden, R.; Carlini, A.; Vucetich, M.; Kay, R; editors), Cambridge University Press: 69-105. Cambridge.

Goin, F.J.; Candela, A.M. 1998. Dos nuevos marsupiales "Pseudodiprotodontes" del Eoceno de Patagonia, Argentina. Asociación Paleontológica Argentina. Publicación Especial Paleógeno de América del Sur y de la Península Antártica 5: 30-12.

Goin, F.J.; Sánchez-Villagra, M.R.; Abello, M.A.; Kay, R.F. 2007. A new generalized paucituberculatan marsupial from the Oligocene of Bolivia and the origin of "shrew-like" opossums. Palaeontology 50: 1267-1276.

Goin, F.J.; Candela, A.M.; Abello, M.A.; Oliveira, E.V. 2009. Earliest South American paucituberculatans and their significance in the understanding of "pseudodiprotodont" marsupial radiations. Zoological Journal of the Linnean Society 155: 867-884.

Gray, J.E. 1821. On the natural arrangement of vertebrose animals. London Medical Repository 15: $296-311$.

Huxley, J.S. 1880. On the application of the law of evolution to the arrangement of the Vertebrata, and more particular to the Mammalia. Proceedings of the Zoological Society of London 43: 649-662.

Illiger, C. 1811. Prodromus systematis mammalium et avium additis terminis zoographicis utriudque classis. Sumptibus C. Salfeld: 301 p. Berlin.

Kramarz, A.G.; Bond, M. 2008. Revision of Parastrapotherium (Mammalia, Astrapotheria) and other Deseadan astrapotheres of Patagonia. Ameghiniana 45: 537-551.

Kramarz, A.G.; Bond, M. 2010. Colhuehuapian Astrapotheriids (Mammalia) from Gran Barranca south of Lake Colhué Huapi. In The Paleontology of Gran Barranca: Evolution and Environmental Change through the Middle Cenozoic of Patagonia (Madden, R.; Carlini, A.; Vucetich, M.; Kay, R; editors). Cambridge University Press: 182-192. Cambridge. 
Kramarz, A.G.; Bond, M. 2014. Reconstruction of the dentition of Propyrotherium Ameghino, 1901 (Mammalia, Pyrotheria). Taxonomic and phylogenetic implications. Journal of Vertebrate Paleontology 34: 434-443.

Kramarz, A.G.; Bond, M.; Forasiepi, A. 2010. New remains of Astraponotus (Mammalia, Astrapotheria) and considerations on the astrapothere cranial evolution. Paläontologische Zeitschrift 85: 185-200.

Linnaeus, C. 1758. Systema naturae per regna tria naturae, secundum classes, ordines, genera, species, cum characteribus, differentiis, synonymis, locis. Editio Decima, reformata. Laurentii Salvii: 824 p. Stockholm.

López, M.G.; Ribeiro, A.M.; Bond, M. 2010. The Notohippidae (Mammalia, Notoungulata) from Gran Barranca: Preliminary Considerations. In The Paleontology of Gran Barranca: Evolution and Environmental Change through the Middle Cenozoic of Patagonia (Madden, R.; Carlini, A.; Vucetich, M.; Kay, R; editors). Cambridge University Press: 143-151. Cambridge.

Lydekker, R. 1894. Contribution to the knowledge of the fossil vertebrates of Argentina. 3. A study of extinct Argentine ungulates. Anales del Museo de La Plata, Paleontología Argentina 2: 1-91.

Marshall, L.G. 1978. Evolution of the Borhyaenidae, extinct South American predaceous marsupials. University of California Publications in Geological Sciences 117: 1-89.

Marshall, L.G. 1980. Systematics of the South American marsupial family Caenolestidae. Fieldiana, Geology New Series 5: 1-145.

Marshall, L.G.; Pascual, R. 1977. Nuevos marsupiales Caenolestidae del "Piso Notohipidense" (SW de Santa Cruz, Argentina) de Ameghino. Sus aportaciones a la cronología y evolución de las comunidades de mamíferos sudamericanos. Publicaciones del Museo Municipal de Ciencias Naturales y Tradicional de Mar del Plata "Lorenzo Scaglia" 2 (4): 91-122.

Martínez, G.; Dozo, M.T.; Vera, B.; Cerdeno, E. 2020. Paleoneurology, auditory region, and associated soft tissue inference in the late Oligocene notoungulates Mendozahippus fierensis and Gualta cuyana (Toxodontia) from central-western Argentina. Journal of Vertebrate Paleontology. doi: 10.1080/02724634.2019.1725531.

Pascual, R.; Bondesio, P.; Vucetich, M.G.; Scillato-Yané, G.J.; Bond, M.; Tonni, E.P. 1984. Vertebrados fósiles cenozoicos. In Congreso Geológico Argentino, No. 19, Relatorio 2: 439-461. Bariloche.

Patterson, B.; Marshall, L.G. 1978. The Deseadan, early Oligocene, Marsupialia of South America. Fieldiana Geology 41: 37-100.

Reguero, M.A.; Goin, F.J. 2021. Paleogeography and biogeography of the Gondwanan final breakup and its terrestrial vertebrates: New insights from southern South America and the "double Noah's Ark" Antarctic Peninsula. Journal of South American Earth Sciences 108 (2021): 103358.

Reguero, M.A.; Croft, D.A.; Flynn, J.J.; Wyss, A.R. 2003. Small Archaeohyracids (Typotheria, Notoungulata) from Chubut Province, Argentina, and Central Chile: Implications for Trans-Andean Temporal Correlation. Fieldiana, Geology New Series. 48: 1-18.

Reig, O.A. 1955. Un nuevo género y especie de cenolestinos del Plioceno de la provincia de Buenos Aires, República Argentina. Revista de la Asociación Geológica Argentina 10: 60-71.

Roth, S. 1899. Aviso preliminar sobre mamíferos mesozoicos encontrados en Patagonia. Revista del Museo de La Plata 9: 381-388.

Roth, S. 1902. Notas sobre algunos nuevos mamíferos fósiles. Revista del Museo de La Plata 10: 252-256.

Roth, S. 1903. Noticias preliminares sobre nuevos mamíferos fósiles del Cretáceo Superior y Terciario de la Patagonia. Revista del Museo de La Plata 11: 133-158.

Simpson, G.G. 1948. The beginning of the Age of Mammals in South America. Part 1. Introduction. Systematics: Marsupialia, Edentata, Condylarthra, Litopterna and Notioprogonia. Bulletin of the American Museum of Natural History 91: 1-232.

Simpson, G.G. 1967. The beginning of the Age of mammals in South America. Part 2. Bulletin of the American Museum of Natural History 137: 1-259.

Shockey, B.J. 1997. Two New Notoungulates (Family Notohippidae) from the Salla Beds of Bolivia (Deseadan: Late Oligocene): Systematics and Functional Morphology. Journal of Vertebrate Paleontology 17: 584-599.

Sinclair, W.J. 1906. Marsupialia. In Reports of the Princeton University Expeditions of Patagonia 1896-1899. Mammalia of the Santa Cruz Beds. IV (III) (Scott, W.B; editor). Princeton University: 333-460. Princeton. 


\section{Supplemetary Information S2}

Eocene mammals from volcaniclastic deposits of the Somun Cura Plateau: biostratigraphic implications for north Patagonia Paleogene TABLE S2. DENTAL MEASUREMENTS (IN CM) OF MAMMALS OF THE LOWER LAS CHACRAS FAUNA.

\begin{tabular}{|c|c|c|c|c|c|c|c|c|c|c|c|c|c|c|c|c|c|c|c|c|c|}
\hline \multirow{2}{*}{ Taxon } & \multirow{2}{*}{ Specimen } & & \multicolumn{2}{|c|}{ c1 } & \multicolumn{2}{|c|}{ p1 } & \multicolumn{2}{|c|}{ p2 } & \multicolumn{2}{|c|}{ p3 } & \multicolumn{2}{|c|}{ p4 } & \multicolumn{2}{|c|}{ m1 } & \multicolumn{2}{|c|}{$\mathrm{m} 2$} & \multicolumn{2}{|c|}{ m3 } & \multicolumn{2}{|c|}{ m4 } & \multirow{2}{*}{ other measurements } \\
\hline & & & mpl & mpw & mpl & mpw & mpl & mpw & $\mathrm{mpl}$ & mpw & mpl & mpw & mpl & mpw & mpl & mpw & mpl & mpw & mpl & mpw & \\
\hline Plesiofelis & MJHG-NCP 58 & - & - & - & 0.7 & 0.36 & 1 & 0.56 & 1.25 & 0.7 & - & - & $1.55^{*}$ & 0.6 & - & - & 1.5 & 0.9 & 1.8 & 1.1 & p1-m4 lenght: 9.4 \\
\hline Pichipilidae & MJHG-NCP 277 & - & - & - & - & - & - & - & - & - & - & - & - & - & 0.24 & 0.16 & - & - & - & - & - \\
\hline Pichipilidae & MJHG-NCP 278 & - & - & - & - & - & - & - & 0.157 & 0.097 & - & - & - & - & - & - & - & - & - & - & - \\
\hline \multirow[t]{2}{*}{ Astraponotus } & MJHG 146Pa & right & - & - & - & - & - & - & - & - & 2.38 & 1.66 & 2.54 & 1.83 & 3.05 & 1.99 & - & - & - & - & - \\
\hline & & left & - & - & - & - & - & - & 3.12 & $1.41^{*}$ & 2.28 & $1.52^{*}$ & - & 1.84 & - & 2 & - & - & - & - & - \\
\hline cf. Astraponotus & MJHG-NCP 269 & - & - & - & - & - & 1.19 & 1.88 & - & - & - & - & - & - & - & - & - & - & - & - & - \\
\hline Propyrotherium & MJHG-NCP 3 & - & - & - & - & - & - & - & - & - & - & - & - & - & 3.87 & 3.04 & - & - & - & - & - \\
\hline Propyrotherium & MJHG-NCP 268 & - & - & - & - & - & - & - & - & - & - & - & 3.5 & 2.37 & - & - & - & - & - & - & - \\
\hline Adianthidae & MJHG-NCP 257 & - & - & - & - & - & - & - & 4.2 & 2.8 & 4.5 & 3 & 4.8 & 3.4 & - & - & - & - & - & - & p3-m1 lenght: 1.34 \\
\hline P. palmeri & MJHG-NCP 11 & - & - & - & - & - & $1.06^{*}$ & $1.42 *$ & 1.63 & 1.3 & 1.97 & 1.38 & 2.5 & 1.58 & 2.94 & 1.88 & - & - & - & - & $\begin{array}{l}\text { p3-m2 lenght: } 87.20 ; \mathrm{p} 3- \\
\text { p4 lenght: } 34.80 ; \mathrm{m} 1-\mathrm{m} 2 \\
\text { lenght:: } 52.40\end{array}$ \\
\hline P. circunflexus & MJHG-NCP 252 & - & - & - & - & - & - & - & 2.44 & 1.68 & 2.66 & 1.75 & 3.16 & 1.92 & - & $2.5^{*}$ & - & - & - & - & - \\
\hline Periphragnis sp. & MJHG 148Pa & - & - & - & - & - & - & - & 1.77 & 1.47 & 1.93 & 1.57 & 2.47 & 1.65 & - & - & - & - & - & - & - \\
\hline Puelia sigma & MJHG-NCP 5 & - & - & - & - & - & - & - & - & - & - & - & - & - & 0.93 & 0.6 & 1.29 & 0.6 & - & - & - \\
\hline Puelia sigma & MJHG-NCP 27 & - & - & - & - & - & - & - & 0.54 & 0.41 & 0.62 & 0.49 & - & - & - & - & - & - & - & - & - \\
\hline Puelia sigma & MACN PV 17589 & - & - & - & - & - & - & - & 0.55 & 0.45 & 0.67 & 0.57 & 0.74 & 0.59 & 0.92 & $0.70^{*}$ & 1.44 & 0.66 & - & - & - \\
\hline Pseudhyrax & MJHG-NCP 7 & - & - & - & - & - & - & - & - & - & - & - & - & - & - & - & 1.38 & 0.67 & - & - & - \\
\hline Pseudhyrax & MJHG-NCP 9 & - & - & - & - & - & 0.75 & 0.39 & - & - & - & - & - & - & - & - & - & - & - & - & - \\
\hline Pseudhyrax & MJHG-NCP 255 & - & - & - & - & - & - & - & - & - & 0.84 & 0.55 & 0.92 & 0.64 & 1.05 & 0.65 & 1.27 & 0.54 & - & - & - \\
\hline Pseudhyrax & MJHG-NCP 259 & - & - & - & 0.47 & 0.24 & 0.81 & 0.37 & 0.84 & 0.52 & 0.77 & 0.55 & - & - & - & - & 1.85 & 0.62 & - & - & - \\
\hline Pseudhyrax & MACN PV 17217 & - & - & - & - & - & 0.79 & 0.35 & 0.85 & 0.49 & 0.83 & 0.55 & 1.01 & 0.61 & 1.03 & 0.54 & - & - & - & - & - \\
\hline- & - & - & - & - & - & - & - & - & - & - & - & - & - & - & - & - & - & - & - & - & - \\
\hline - & - & - & & 1 & & & & & & & & & $\mathbf{N}$ & & N & & & & - & - & - \\
\hline- & - & - & mpl & mpw & $\mathrm{mpl}$ & mpw & mpl & mpw & $\mathrm{mpl}$ & mpw & $\mathrm{mpl}$ & mpw & mpl & mpw & mpl & mpw & mpl & mpw & - & - & - \\
\hline Astraponotus & MJHG-NCP 251 & - & 3.38 & 2.68 & & & 1.68 & 1.52 & 2.11 & 2.75 & 2.14 & 3.18 & 2.37 & 3.78 & 2.9 & 3.92 & 3.38 & 3.78 & - & - & $\begin{array}{l}\text { P2-M3 lenght: } 13.85 \\
\text { M1-M3 lenght: } 8.5\end{array}$ \\
\hline cf. Astraponotus & MJHG-NCP 269 & - & - & - & - & - & - & - & - & - & 1.83 & 2.53 & - & - & - & - & - & - & - & - & - \\
\hline Astraponotus & MJHG 146Pa & - & - & - & - & - & 1.74 & 1.79 & - & - & - & - & - & - & - & - & - & - & - & - & - \\
\hline P. palmeri & MJHG-NCP 12 & - & - & - & - & - & - & - & - & - & - & - & - & - & 2.55 & 3 & 2.74 & $2.9^{*}$ & - & - & - \\
\hline Puelia & MJHG-NCP 2 & - & - & - & 0.51 & 0.51 & 0.57 & 0.77 & 0.72 & 0.72 & - & - & 1.03 & 1.18 & 1.14 & 1.27 & 1.11 & 1.13 & - & - & - \\
\hline Pseudhyrax & MJHG-NCP 8 & - & - & - & - & - & - & - & - & - & 0.84 & 0.9 & 0.89 & 1.04 & - & - & - & - & - & - & - \\
\hline Pseudhyrax & MJHG-NCP 263 & - & - & - & 0.78 & 0.67 & - & - & - & - & - & - & - & - & - & - & - & - & - & - & - \\
\hline Eohegetotherium & MJHG-NCP 264 & - & - & - & - & - & - & - & - & - & - & - & 0.57 & 0.51 & - & - & - & - & - & - & - \\
\hline
\end{tabular}

Abbreviartions: mpl: maximum preserved mesio-distal lenght; mpw: maximum preserved labio-lingual width. Asterisk denotes approximate measurement. 